\title{
Bibliográfia
}

\section{A 2012-ben megjelent, jog- és államtudományi tárgyú könyvek annotált bibliográfiája - 1. rész}

Folyóiratunkban rendszeresen jelenik meg az elmúlt időszak új, hazai szakkönyveiröl készült, annotált bibliográfia. Az annotáció a könyv felhasználhatóságáról írott, rövid, tényszerủ leírás, amely a bibliográfiai adatok mellett meghatározza a múfajt, illetve röviden körvonalazza a feldolgozott témát és a bemutatott eredményeket is. A mostani számban a 2012-ben megjelent könyvek mintegy felét dolgozzuk fel, s a 2014/2. számban közöljük a hátralévőket, reményeink szerint teljes körüen. Annak megfelelően, hogy a Magyar Tudományos Művek Tára (MTMT) csak a 120 oldal terjedelmet elérő munkákat kezeli önálló kiadványként, az ettől jelentősen elmaradó kiadványokkal mi sem foglalkozunk. A bemutatás az alábbi sorrendet követi: alkotmányjog és emberi jogok, büntetőjog és büntetőeljárási jog, Európa-jog, jogtörténet és jogbölcselet, közigazgatási jog, munkajog, pénzügyi jog, polgári jog és polgári eljárásjog.

Első lépésként ezúttal is egy listát állítottunk össze különböző intézményi könyvtári katalógusok, a Magyar Országos Közös Katalógus (MOKKA), illetve az Országos Széchényi Könyvtár interneten is közölt adatai alapján. Emellett kiadók honlapján, hírlevelekben, a szerzők publikációs listáiban és saját könyvespolcainkon is kutattunk. Gyűjtőmunkánkat jelentős mértékben segítette a Debreceni Egyetem Egyetemi és Nemzeti Könyvtára, amely köteles könyvtárként a hazai kiadványok gyűjtését, feldolgozását, illetve részben - a mienkhez képest némileg eltérő szempontok szerint - annotálását is elvégzi. Ettől az évtől kezdve a könyvtár munkatársai egyéb adatbázisokat is figyelembe véve egészíti ki a listánkat, így az még pontosabb és teljesebb a korábbiaknál.

A leírások elkészítése során általában a szerzők, kiadók által készített fülszövegeket, ajánlásokat, illetve a kötetekröl készült recenziókat is igyekeztünk fellelni és hasznosítani. Az annotációk azonban minden esetben úgy készültek, hogy az adott könyvet is a kezünkbe vettük, s ehhez, ha kellett, könyvtárközi kölcsönzéssel vagy más intézményekben dolgozó kollégáktól megkértük. Az annotációk tehát önálló feldolgozó munka eredményei.

Tisztában vagyunk azzal, hogy a feldolgozás szempontrendszere legjobb igyekezetünk ellenére is hiányos, illetve a sok szakterület és közremüködő okán egyenetlen. Örömmel veszünk és meg is szívlelünk ezért minden észrevételt, amely mun- 
kánkra vonatkozóan szerkesztőségünkhöz beérkezik. Szívesen fogadjuk azt is, ha a szerzők figyelmünkbe ajánlják saját könyvüket.

A rovat belső szerkesztési elve szerint a kiadványokat témák (jogterületek) szerint csoportosítottuk. A leírások első, rövidebb része tartalmazza a könyvészeti adatokat (cím, szerző/szerkesztő, a kiadó neve, a kiadás helye és éve) az arra való utalással, hogy van-e a könyvben bibliográfia (irodalomjegyzék), illetve hogy a könyv milyen müfajba sorolható be. A terjedelmet oldalszámban adjuk meg, s közöljük a kötet azonosítására szolgáló ISBN-t, illetve sorozatok esetében az ISSN-t. A második rész röviden leírja az alkotót, illetve alkotókat. Ezt követően (a változatlan utánnyomások kivételével) általában 6-12 sor terjedelemben számba vesszük a mü tárgyköreit, föbb eredményeit. Az eredmények részletes értékelését azonban nem végezzük el. A háromnál több szerzős, illetve a gyűjteményes munkák esetében nem kerül sor valamennyi szerző név szerinti megemlítésére, s a tanulmányok számától, tematikai egymáshoz kapcsolódásától függ, hogy minden témát megnevezünk-e. A felsőoktatási tananyagok, jogszabályközlések bemutatását a lehető legtömörebben végezzük el.

Az alább közölt annotációk elkészítésében a Debreceni Egyetem Állam- és Jogtudományi Karának munkatársai, illetve hallgatói működtek közre: Árva Zsuzsanna (Á. Zs.) egyetemi docens, Bagdi Katalin (B. K.) PhD-hallgató, Bagossy Mária (B. M.) joghallgató, Barta Attila (B. A.) egyetemi adjunktus, Balogh Éva (B. É.) PhD-hallgató, Bodó László (B. L.) PhD-hallgató, Bujdos Ágnes (B. Á.) PhD-hallgató, Nagyné Dorka Dóra (D. D.) PhD-hallgató, Fazekas Flóra (F. F.) egyetemi adjunktus, Fekete Péter Pál (F. P. P.) joghallgató, Ferenczy Áron (F. Á.) joghallgató, Gócza Ágnes (G. Á.) joghallgató, Háger Tamás (H. T.) bíró, PhD-hallgató, Hati Csilla (H. Cs.) joghallgató, Gyüre Annamária Csilla (Gy. A. Cs.) PhD-hallgató, Keresztes Gergő Márk (K. G. M.) joghallgató, Kiss János Márk (K. J. M.) joghallgató, Kőmüves Barbara (K. B.) joghallgató, Lukács Nikolett (L. N.) PhD-hallgató, Papp Olga (P. O.) PhD-hallgató, Perger Csaba (P. Cs.) joghallgató, Tomasovszky Edit (T. E.) PhD-hallgató, Tóth Andrea Noémi (T. A. N.) PhD-hallgató, Török Éva (T. É.) egyetemi tanársegéd, Ugrai Katalin (U. K.) joghallgató, Veszprémi Bernadett (V. B.) egyetemi adjunktus, Zsugyó Virág (Zs. V.) PhD-hallgató, Zsoldics Zsófia (Zs. Zs.) PhD-hallgató.

\section{ALKOTMÁNYJOG, EMBERI JOGOK}

- Conversations on the fundamental law of Hungary: interviews with József Szájer, hungarian member of European Parliament, and Gergely Gulyás, member of Parliament in Hungary

ABLONCZY Bálint

Kozma Zsolt (ford.)

Elektromédia, Kerepes, 2012

Interjúkötet. Terjedelem: 225. Bibliográfia nincs. ISBN 9789638824073

Gespräche über das Grundgesetz Ungarns: Bálint Ablonczy im Gespräch mit József Szájer und Gergely Gulyás

Ablonczy Bálint

Turai Orsolya (ford.) 
Elektromédia, Kerepes, 2012

Interjúkötet. Terjedelem: 234. Bibliográfia nincs. ISBN 9789638824066

Sur les traces de la constitution hongroise: entretiens avec József Szájer et Gergely Gulyás

ABLonCZy Bálint

Nyerges Dániel (ford.)

Elektromédia, Kerepes, 2012

Interjúkötet. Terjedelem: 227. Bibliográfia nincs. ISBN 9789638824097

- A szerző újságíró. A kötetek a 2011-ben magyarul megjelent Az alkotmány nyomában: beszélgetések Szájer Józseffel és Gulyás Gergellyel címú interjúkötet angol, német és francia nyelvű változatai. Az interjú során számos kevéssé ismert választás, dilemma részleteire derül fény az Alaptörvény keletkezésével kapcsolatban, amelyek körül közéleti, politikai viták bontakoztak ki 2011 tavaszán. Az egyes kötetek végén angolul, németül és franciául olvasható az Alaptörvény 2011-ben hatályos szövege. (Zs. V.)

- Változások a magyar alkotmányjogban: tanulmányok az Alaptörvényröl Balogh Elemér-Cserny Ákos-Patyi András-Téglási András (szerk.) (Sorozat: Hallgatói Közjogi Dolgozatok, ISSN 2063-7772; 1.)

Nemzeti Közszolgálati és Tankönyv Kiadó, Budapest, 2012

Tanulmánykötet. Terjedelem: 320. Bibliográfia: 309-320. ISBN 9789630855921

- A szerzők egyetemi hallgatók és oktatók. A kötet a Budapesti Corvinus Egyetem Közigazgatás-tudományi Karán (az NKE KIK jogelődje) 2011. november 18-án tartott alkotmányjogi tudományos diákköri konferencia szerkesztett anyagát tartalmazza. 14 tudományos diákköri tanulmányt közöl, amelyek mindegyikéhez korreferátum kapcsolódik. A korreferensek az adott témában elismert szakemberek, akik segítséget nyújthatnak a hallgatóknak tudományos kutatásuk elmélyítésében. A tanulmányok többek között az Alkotmánybíróság hatásköreivel, a határon túli magyarok választójogával, az ombudsmani rendszerrel, a gyülekezési joggal foglalkoznak. (Zs. V.)

- Alkotmányjog: jogi szakvizsga jegyzet

CsINK Lóránt

Novissima, Budapest, 2012

(Sorozat: Jogi Szakvizsga Kézikönyvek, ISSN 1786-0806)

Tankönyv. Terjedelem: 367. Bibliográfia nincs. ISBN 9786155175466

- A szerző egyetemi oktató, az alapvető jogok biztosának munkatársa. A jegyzet elsősorban a szakvizsgára készülők számára nyújt segítséget az alkotmányjogi tanulmányokhoz. A könyv megjelenését a 2010-ben megkezdődött közjogi átalakulás, illetve főként az Alaptörvény hatálybalépése és az ezzel járó alapvető változások indokolták. A kötet a jogi szakvizsga tételsorához igazodik, így elsőként az alapvető jogokat, majd az államszervezetet tárgyalja. A jegyzet összegyüjtve és rendszerezve tartalmazza az egyes tételekhez kapcsolódó jogszabályi rendelkezéseket. A joganyag értelmezésének megkönnyítése érdekében feldolgozza a vonatkozó alkotmánybírósági határozatok is. (B. É.) 
- Egy alkotmány margójára: alkotmányelméleti és értelmezési kérdések az Alaptörvényröl

CsINK Lóránt-FRÖHLICH Johanna

Gondolat, Budapest, 2012

Kézikönyv. Terjedelem: 166. Bibliográfia: 159-166. és a lábjegyzetekben.

ISBN 9789636934309

- Csink Lóránt egyetemi oktató, az alapvető jogok biztosának munkatársa, Fröhlich Johanna egyetemi oktató, az Alkotmánybíróság tanácsadója. A szerzők e kötetben arra vállalkoznak, hogy a 2010-es parlamenti választásokat követő közjogi átalakulást folyamatában szemlélve, az annak középpontjában lévő dokumentumot, az Alaptörvényt értelmezzék. Ennek érdekében általánosságban is vizsgálják az alkotmány sajátosságait, illetve az alkotmányértelmezés szerepét. Válaszokat keresnek a majdani gyakorlat esetleges kérdéseire is. A szerzőpáros munkájával az aktuális alkotmányjogi dilemmákról szóló diskurzusba kíván bekapcsolódni, így a kötetet e párbeszéd résztvevőinek ajánlja. (B. É.)

- Alkotmányozás Magyarországon és máshol: politikatudományi és alkotmányjogi megközelítések

Jakab András-Körösényi András (szerk.)

MTA TK PTI - Új Mandátum Könyvkiadó, Budapest, 2012

Konferenciakötet. Terjedelem: 309. Bibliográfia a lábjegyzetekben.

ISBN 9789632870519

- A szerkesztők az MTA JTI, illetve az MTA PTI igazgatói, a szerzők alkotmányjogászok, politikatudósok. A kötet az MTA Politikatudományi Intézetében 2010. december 20-án, az alkotmányozás témakörében rendezett konferencia előadásainak írásos anyagát tartalmazza. A konferencia és egyben a kötet célja az volt, hogy kiemelje az alkotmányozás kérdését az aktuális napi politikából, mégis olyan ismereteket nyújtson, amelyek segítségével a pillanatnyi magyar helyzet megértését is segíti. A kötetben három nagy szerkezeti egység különül el: az I. részben elméleti és eszmetörténeti írások találhatók, a II. részben alkotmányozási eljárások bemutatására kerül sor, a III. rész pedig a magyarországi alkotmányozásokra (1989-2010) koncentrál. A kötet teljes terjedelmében hozzáférhető az MTA PTI honlapján is. (B. É.)

- Összehasonlító alkotmányjog: az államszervezet

KILÉNYI Géza

Pázmány Press, Budapest, 2012

(Sorozat: A Pázmány Péter Katolikus Egyetem Jog- és Államtudományi Karának Tankönyvei, ISSN 2062-0837)

Tankönyv. Terjedelem: 280. Bibliográfia nincs. ISBN 9789633080795

- A szerző egyetemi tanár, volt alkotmánybíró. A tankönyv célja, hogy az alkotmányfejlődés folyamatában összehasonlító jogi módszerrel vizsgálja egyes államok alkotmányos rendszereit, illetve az egyes alkotmányjogi intézmények fejlődésének tendenciáit. A kötet elsőként a népröl mint hatalmi tényezőröl, illetve az alkotmányozó hatalomról, majd magáról az alkotmányozásról szól. Ezt követően az 
egyes jogintézményeket veszi sorra, elemzi a külföldi alkotmányok államszervezetre vonatkozó rendelkezéseit, majd összeveti ezeket a hatályos magyar alkotmányjogi szabályokkal. (B. É.)

- Magyar és európai médiajog

Koltay András-Nyakas Levente (szerk.)

CompLex, Budapest, 2012

Kézikönyv. Terjedelem: 929. Bibliográfia a jegyzetekben. ISBN 9789632952222

- A szerkesztők egyetemi oktatók, Koltay András a Médiatanács tagja. A kötet a média szabályozását - így a sajtószabadságot mint alapjogot, az egyes médiumok igazgatási kérdéseit, valamint a hatósági szabályozást - komplex módon, a teljesség igényével kívánja bemutatni. A szerzők arra törekedtek, hogy a médiaszabályozást annak átpolitizáltsága ellenére objektív szempontok alapján ismertessék. A könyv az egyes témaköröket azok történetiségében vizsgálja, a magyar szabályozás európai összefüggéseit is feltárja. A hatályos joganyag áttekintésén túl a bírói gyakorlat, illetve a különböző hatóságok gyakorlatának ismertetésére is kitér. (B. É.)

- Alkotmányjog: Bachelor szakos hallgatók számára

Paulovics Anita (szerk.)

Miskolci Egyetemi Kiadó, Miskolc, 2012

Egyetemi jegyzet. Terjedelem: 143. Bibliográfia: 143. ISBN 9786155216329

- A szerzők miskolci egyetemi oktatók, illetve gyakorlati szakemberek. A kötet (amelynek előző változata 2006-ban jelent meg, egy másik kiadónál) azzal a céllal készült, hogy az alapképzésben részt vevő hallgatók átfogó képet kapjanak az alkotmányjog alapjairól. A jegyzet főként államszervezeti kérdésekkel foglalkozik, így bemutatja az Országgyűlésre, a köztársasági elnökre, a Kormányra, a bíróságokra, az ügyészségre, az Alkotmánybíróságra és az alapvető jogok biztosára vonatkozó szabályokat és föbb elveket. Ezen túl tárgyalja a jogforrási rendszert, a választójogot és a népszavazást, és röviden kitér az alapvető jogok csoportosítására, szabályozására és korlátozásának módjára is. (Zs. V.)

- Alkotmányos alapok

Pozsár-Szentmiklósy Zoltán-Somody Bernadette (szerk.)

HVG-ORAC, Budapest, 2012

Egyetemi jegyzet. Terjedelem: 263. Bibliográfia nincs. ISBN 9789632581811

- A szerkesztők és a szerzők egyetemi oktatók. A kötet az ELTE ÁJK Alkotmányjogi Tanszékének mühelyében tananyagként készült azok számára, akik felsőoktatásban, de nem jogtudományi képzésben tanulnak alkotmányjogi ismereteket. Így áttekintést ad az alkotmányos alapelvekről, az alkotmányos értékekről, illetve az alapvető alkotmányos intézményekről, majd e keretet alapul véve mutatja be a magyar alkotmányjog legfőbb szabályait. A kötet figyelemmel van a 2010-2011-es alkotmányos változásokra, így feldolgozza a 2011-ben elfogadott Alaptörvénynek és az ahhoz kapcsolódó törvényeknek a legfontosabb rendelkezéseit. (B. É.) 
- A történeti alkotmány helye mai jogunkban

RIXER Ádám

KRE ÁJK, Budapest, 2012

(Sorozat: Lőrincz Lajos Közjogi Kutatóműhely, Vitasorozat; 1. ISSN 2063-9554)

Tanulmány. Terjedelem: 93. Bibliográfia: 83-96. ISBN 9789639808362

- A szerző egyetemi oktató. Tanulmánya a KRE ÁJK Lőrincz Lajos Közjogi Kutatómúhely Vitasorozatának egyik eleme. A vitasorozat e darabja a történeti alkotmány fogalmával, tartalmával és az azt körülvevő jogi környezettel, az e körben felmerülő értelmezési és egyéb problémákkal foglalkozik. A történeti alkotmány, amelynek jelentősége az Alaptörvény szövegében való megjelenése miatt megnőtt, a jogi környezetben bizonytalan tartalmú fogalom. Erre tekintettel a szerző igyekszik meghatározni a történeti alkotmány esetleges jövőbeli jelentéseit. ( $B$. É.)

- A magyar jogrendszer jellegzetességei 2010 után

RIXER Ádám

Patrocinium, Budapest, 2012

(Sorozat: Bethlen-sorozat, ISSN 2062-2546)

Kézikönyv. Terjedelem: 165. Bibliográfia az egyes fejezetek végén.

ISBN 9786155107801

- A szerző egyetemi oktató. A kötet célja, hogy a 2010-ben elkezdődött közjogi átalakulás eredményeként a magyar jogrendszerben bekövetkezett hangsúlyelmozdulásokat bemutassa. Ebben a kontextusban foglalkozik a szerző a jogrendszer általa természetjogiasnak nevezett átalakulásával, azaz a mögöttes értékeket és érdekeket előtérbe helyező jogszemlélet új irányával. Ennek során a 2010-2012 között érzékelhető legfontosabb társadalmi-politikai folyamatokat, a jogintézmények, a joggyakorlat és a jogi gondolkodás változásait tárja fel. A kötet angol nyelven is megjelent Features of the Hungarian Legal System after 2010 címmel, és teljes terjedelmében elérhető a kiadó honlapján. (B. É.)

- Az információs hatalom alkotmányos korlátai

Szabó Máté Dániel

Miskolci Egyetem, Miskolc, 2012

Monográfia. Terjedelem: 207. Bibliográfia: 191-205. és a jegyzetekben. ISBN 9789636619916

- A szerző egyetemi oktató. Munkájának kiindulópontja az, hogy az információ birtoklása az első lépés a politikai és gazdasági hatalom megszerzése felé, az információhoz való hozzáférés döntő abban a kérdésben, hogy ki mit tehet. Ebből következik a rendkívül fontos kérdés: ki mit tudhat, és kiröl mi tudható. A könyv azzal foglalkozik, hogy melyek az információhoz való hozzáférésben rejlő hatalom korlátai, képes-e a jog korlátozni ezt a hatalmat, és amennyiben igen, milyen eszközökkel. A témát újszerü megközelítésben tárgyalja: azt vizsgálja, hogy az alapjogok hogyan tudják korlátozni ezt a speciális hatalomtípust. A jogi eszközöket abból a szempontból elemzi, hogy azok mennyiben szolgálják az információs aszimmetria által okozott egyensúlytalan helyzet egyensúlyi állapot felé való elmozdulását. (B. É.) 
- Tansegédlet az alkotmányjogi záróvizsgához

SZABÓ Zsolt

(Sorozat: Werbőczy-sorozat, ISSN 2062-2538)

Patrocinium, Budapest, 2012

Tansegédlet. Terjedelem: 185. Bibliográfia nincs. ISBN 9786155107788

- A szerző egyetemi oktató, tansegédlete a Károli Gáspár Református Egyetem Állam- és Jogtudományi Karán hivatott az alkotmányjogi záróvizsgára való felkészülést megkönnyíteni. Az egyes államszervezeti és alapjogi tételekhez kapcsolódó legfontosabb ismereteket vázlatos formában tartalmazza. Az egyes tételek összefoglalása segítséget nyújt az igen nagy terjedelmű joganyag elsajátításához. A szerző a Trócsányi László és Schanda Balázs által szerkesztett, illetve a Csink Lóránt által írt alkotmányjogi tankönyveket vette alapul - mindkettő 2012-es megjelenésü. (Zs. V.)

- Constitution for a Disunited Nation: On Hungary's 2011 Fundamental Law

Tóth, Gábor Attila (szerk.)

Central European University Press, Budapest-New York, 2012

Tanulmánykötet. Terjedelem: 570. Bibliográfia: 537-549. ISBN 9786155225185

- A szerkesztő egyetemi oktató, a tanulmányok szerzői neves magyar és külföldi alkotmányjogászok. A kötetben szereplő tanulmányok arra a kérdésre keresik a választ, hogy Magyarország Alaptörvénye mennyiben teljesíti a demokratikus alkotmányok azon feladatát, hogy olyan elveket és eljárásokat fektessen le, amelyek tekintetében a politikai közösség tagjai között konszenzus van, s amelyek alapján megvalósulhat a közösségi együttműködés. A szerzők álláspontja az, hogy ezen elvárásnak az Alaptörvény kevéssé felel meg, és inkább megosztja a közösséget, mintsem integrálja azt. A könyv kiemelkedő szerepet tölthet be abban a diskurzusban, amely a politikai legitimáció, a demokrácia és az alkotmányosság kérdéseit érinti. (B. É.)

- Bevezetés az alkotmányjogba: az Alaptörvény és Magyarország alkotmányos intézményei

Trócsányi László-Schanda Balázs (szerk.)

HVG-ORAC, Budapest, 2012

Tankönyv. Terjedelem: 455. Bibliográfia fejezetenként. ISBN 9789632581521

- A szerkesztők egyetemi tanárok. A kötet a Pázmány Péter Katolikus Egyetem, illetve a Szegedi és a Debreceni Egyetem jogi karának együttműködésében készült. Az Alaptörvény és az ahhoz kapcsolódóan elfogadott, új, sarkalatos törvények alapján az alkotmányjogi stúdium államszervezeti témaköreit dolgozza fel, összefoglaló jelleggel betekintést nyújt az új alkotmányos intézményrendszerbe, kitér továbbá az Alaptörvény keletkezésének körülményeire is. E kötet volt az első olyan tankönyv, amely a 2011-es közjogi átalakulás után jelent meg. (Zs. V.)

- Alkotmányos alapismeretek: segédanyag az állampolgársági vizsgára készülő nem magyar állampolgárok számára a 2012. január 1-jén életbe lépett Alaptörvény szerint 
UGRÓCZKY Mária

Harmadik, átdolgozott, javított kiadás. SL és Társa Bt., Telki, 2012

Tansegédlet. Terjedelem: 120. Bibliográfia nincs. ISBN 9789638920805

- A szerző főiskolai oktató, könyve azt a célt szolgálja, hogy elősegítse a nem magyar származású külföldi állampolgárok, hontalanok felkészülését a magyar állampolgárság megszerzéséhez szükséges alkotmányos alapismeretek vizsgára. A segédanyag kitér Magyarország államszervezetére, szokásaira, kultúrájára, történelmére, irodalmára és az alapvető állampolgári jogokra és kötelességekre, valamint röviden bemutatja országunk helyét Európában és a nemzetközi együttmüködésben. (Zs. V.)

\section{BÜNTETŐJOG ÉS BÜNTETŐELJÁRÁSI JOG}

- Büntetőeljárási jog I. és II.

BartKó Róbert-DÁvid Lilla-Horváth Péter-Jungl Eszter-Kovács Gábor-NAGY Klára-NÉMETH Imre

Universitas-Győr Nonprofit Kft., Győr, 2012

Egyetemi jegyzet. Terjedelem: 408 és 319.

ISBN 9789639819948 és 9786155298035

- Minden szerző a győri egyetem oktatója, akik a büntető eljárási jog oktatása és tanulása során jól hasznosítható könyvet készítettek el, két részben. Az első a nyomozásra vonatkozó szabályanyag bemutatásával zárul, míg az eljárás dinamikus részének feldolgozása a második kötetben található. A kiadvány sajátossága, a tananyag részletes bemutatása és áttekintő táblázatok használata mellett, hogy a második kötet a leggyakrabban előforduló iratmintákkal zárul, a leírt ismeretek gyakorlati hasznosíthatósága érdekében. Nemcsak a törvény szabályainak ismertetésére szorítkozik, hanem igyekszik felvonultatni a kapcsolódó bírósági döntéseket is, és az egyes fejezetek végén ajánlott irodalmat is találunk. (T. A. N.)

- Büntetőjog I. Általános rész - A 2012. évi C. törvény alapján

Belovics Ervin-Gellér Balázs-Nagy Ferenc-Tóth Mihály

HVG-ORAC Lap- és Könyvkiadó, Budapest, 2012

Tankönyv. Terjedelem: 568. ISBN 9789632581705

- A könyv szerzői az ország négy jogi karán büntetőjogi tanszékek vezetői, gyakorlati szakemberek. A mü megírását az új büntető törvénykönyv 2012-es elfogadása ösztönözte. A könyv a Büntető törvénykönyv Általános részét dolgozza fel mélyrehatóan. Bemutatja a történeti előzményeket, a különböző jogirodalmi álláspontokat. A mủ vázolja a büntetőjog fogalmi rendjét, dogmatikai jellemzését, továbbá a kriminológiai célkitüzések érdekében tett lépéseket, illetve azok korlátait. Elemzi a nemzetközi és a magyar büntetőjogi intézményrendszerek összefüggéseit, rávilágít a felmerülő jogharmonizációs igényekre. Az elméleti elemzés mellett az olvasó megismerheti az irányadó joggyakorlatot. Megkönnyíti a szövegben történő eligazodást a könyv elején található jelmagyarázat, ami segít az adott szövegrészek mellett elhelyezkedő szimbólumok értelmezésében. (G. Á.) 
- Büntetőjog II. Különös rész - A 2012. évi C. törvény alapján

Belovics Ervin-MolnáR Gábor Miklós-SinKu Pál

HVG-ORAC Lap- és Könyvkiadó, Budapest, 2012

Terjedelem: 863. ISBN 9789632581804

- A könyv írói gyakorlati szakemberek és egyetemi oktatók is egyaránt. Az új Büntető törvénykönyv Különös részében szabályozott tényállásokat elemzi a könyv, amely ezt megelőzően már kilenc kiadásban megjelent. A hagyományos dogmatikai elemzésen túl kitér a mú az európai jogi gondolkodás és a magyar büntetőjog-tudomány történeti kapcsolatára, a büntetőjog fejlődésére és elveire. Az elméleti elemzés mellett az olvasó megismerheti az irányadó joggyakorlatot is. Megkönnyíti a szövegben történő eligazodást a könyv elején található jelmagyarázat, amely segít az adott szövegrészek mellett elhelyezkedő szimbólumok értelmezésében. (G. Á.)

- A jogerő a büntetőeljárásban

ELEk Balázs

Debreceni Egyetem Állam és Jogtudományi Kar Büntető Eljárásjogi Tanszéke, Debrecen, 2012

Monográfia. Terjedelem: 316. Bibliográfia: 298-312. és a lábjegyzetekben. ISBN 9789634735984

- A szerző egyetemi oktató, bíró. Az igazság és a valós tényállás megállapítására irányuló törekvés rögzítése mellett a jogerő - mint a jogbiztonság egyik garanciája - vonatkozásában részletesen bemutatja annak egyes típusait, feloldásának különböző eszközeit, illetve számba veszi, csoportosítja és értelmezi a büntetőeljárás valamennyi határozatát a jogerőre képesség szempontjából. A szerzőnek a hiányos jogszabályi rendelkezések és az eltérő álláspontot képviselő jogtudományi munkák, vonatkozó büntetőbírósági határozatok elemzése során megfogalmazott véleménye elméleti és gyakorlati szempontból egyaránt érdekes. $(H$. Cs.)

- Az orvosszakértő a büntetőeljárásban

Elek Balázs (szerk.)

Debreceni Egyetem Állam és Jogtudományi Kar Büntető Eljárásjogi Tanszéke, Debrecen, 2012

Tanulmánykötet. Terjedelem: 150. Bibliográfia a lábjegyzetekben. ISBN 9789634735496

- A szerzők jogászok, illetve gyakorló orvosok és orvosszakértők. A tanulmánykötetben megjelenő tanulmányok jogászi, illetve orvosszakértői nézőpontból is elemzik a szakértői bizonyítással kapcsolatos eljárási szabályokat és szabályszegéseket, a szakértő büntetőeljárásbeli szerepét. Jogászok tollából megismerhetjük az orvosszakértői vélemény jelentőségét a perújítási eljárás és a távoltartás elrendelésére irányuló eljárás kapcsán; a valószínüségi szakvélemény és az ártatlanság vélelmének viszonyát; az orvosi tevékenységgel kapcsolatos felelősség büntető anyagi jogi szabályait. A témakör orvosi, orvosszakértői szempontból történő kifejtése színesíti, árnyalja, s több esetben meg is kérdőjelezi a nevesített jogszabályi rendelkezések helyességét. (H. Cs.) 
- A büntető tárgyalási rendszerek sajátosságai és a büntetőeljárás hatékonysága FANTOLY Zsanett HVG-ORAC, Budapest, 2012 Monográfia. Terjedelem: 332. Bibliográfia: 307-332. ISBN 9789632581842

- A szerző egyetemi oktató, aki a kötet első részében az akkuzatórius és inkvizitórius büntetőeljárás modelljeit, majd azok várható fejlődési irányait mutatja be az egyes jogintézmények adaptálhatósága tükrében. A mü egyik kuriózuma a nemzetközi bíróságok tárgyalási rendszereinek bemutatása, összehasonlító elemzéssel, amelynek során felvázolja a jövőbeni lehetséges változásokat is. A kötet második része a büntetőeljárás hatékonyságának problémakörét a hazai viszonyokra koncentrálva ismerteti, a gyorsítást szolgáló jogintézmények áttekintésével. (T. A. N.)

- A büntetőeljárás

FARKAS Ákos-Róth Erika

CompLex Kiadó, Budapest, 2012

Tankönyv. Terjedelem: 502. Bibliográfia: 491-502. ISBN 9789632950624

- A szerzők a Miskolci Egyetem Állam- és Jogtudományi Kar Büntető Eljárásjogi és Büntetés-végrehajtási Jogi Tanszékének oktatói. Tankönyvük a jogi oktatás büntető eljárásjogi tananyagának elsajátításában nyújt hatékony segítséget. $A$ büntetőeljárási jog alapfogalmai mellett az általános rendelkezések, a bizonyítás, a nyomozás, a vádemelés, az elsőfokú eljárás, valamint a jogorvoslati eljárások jól áttekinthető megközelítésével világítja meg a fontos elméleti és gyakorlati kérdéseket. A hazai és a külföldi szakirodalom nagyszámú forrására támaszkodva elemzi a büntetőeljárás kardinális jogintézményeit, eljárási cselekményeit. Kitér büntetőeljárásunk minden lényeges részére, és megfelelő támpontot ad nemcsak a joghallgatók, de a jogtudomány, valamint az érdeklődő jogkereső állampolgárok számára is az eljárás lényegi elemeinek alapos megismeréséhez. (H. T.)

- A francia és az olasz büntetőeljárás alapintézményei

HERKE Csongor

PTE ÁJK, Pécs, 2012

Monográfia. Terjedelem: 115. Bibliográfia 107-108. ISBN 9789636424404

- A szerző egyetemi oktató. Arra törekedett, hogy a hazai jogirodalomban hiánypótló módon, a maga egészében mutassa be a francia és olasz büntetőeljárást, mégpedig egymással párhuzamosan. A könyv a két állam szabályait számos szempont alapján ismerteti, úgymint az alapvető rendelkezések, a hatóságok, a résztvevők, a bizonyítékok, az alkalmazható kényszerintézkedések, a nyomozás, a közbenső eljárás, az elsőfokú eljárás, az igénybe vehető perorvoslatok, valamint a sértetti vádképviselet és a különeljárások témaköre. A könnyebb tájékozódást rövidítések jegyzéke segíti a könyv végén. (T. A. N.)

- Büntető eljárásjog

HeRke Csongor

178 (Sorozat: Dialóg Campus Szakkönyvek, ISSN 1417-7986; Jogi szakvizsga segédkönyvek, ISSN 1587-6659) 
Negyedik kiadás. Dialóg Campus Kiadó, Budapest-Pécs, 2012 Monográfia. Terjedelem: 381. ISBN 9789639950849

- A Pécsi Tudományegyetem oktatója kifejezetten a jogi szakvizsga előtt állók számára készítette el a könyvet, amelynek újabb kiadását a bekövetkezett jogszabályváltozások indokolták. A kötet elsősorban a büntetőeljárásról szóló törvény szabályait rendszerezi, és kiegészíti a kapcsolódó jogszabályokkal, az Alkotmánybíróság vonatkozó határozataival, a Kúria döntéseivel, valamint jogegységi határozatokkal, melyeket külön rendszerezve is felsorol. Tematikája a szakvizsgához igazodik, így elengedhetetlen a kötet jelentős részét kitevő iratmintatár, amely a könnyebb áttekinthetőség érdekében a büntetőeljárás szakaszaihoz igazodik. (T. A. N.)

- Emberkereskedelem

HOLLÁn Miklós

HVG-ORAC Lap- és Könyvkiadó, Budapest, 2012

Monográfia. Terjedelem: 343. Bibliográfia: 321-339. ISBN 9789632581484

- A szerző az MTA TK JTI tudományos főmunkatársa, emellett egyetemi oktató. A monográfia részletesen bemutatja azt a nemzetközi és európai uniós szabályrendszert, amely az államokat nemzeti büntetőjogi szabályok megalkotására kötelezi az emberkereskedelem vonatkozásában. A kutatás kitér az osztrák, a svájci és az angol szabályozás bemutatására. Ezen országok joganyaga a jogharmonizációs kötelezettségek teljesítésével kapcsolatban a szerző szerint a legtöbb tanulsággal szolgál a magyar büntetőjog számára. Az írás utolsó nagy egysége a hazai jog emberkereskedelemre vonatkozó szabályozástörténettel foglalkozik, vizsgálva a nemzetközi kötelezettségek teljesítését és az alapjogi követelmények betartását. A szerző a joganyag feldolgozásában összehasonlító, történeti és dogmatikai módszert is alkalmaz. A könnyebb eligazodást a szöveg végén található tárgymutató segíti. (G. Á.)

- A fenyítőházak forradalma

Mezey Barna

Gondolat Kiadó, Budapest, 2012

Monográfia. Terjedelem: 540. Bibliográfia: 453-478. és a lábjegyzetekben. ISBN 978963435

- A szerző egyetemi oktató, a Magyar Tudományos Akadémia doktora. A modern börtönig vezető fejlődés részleteit, a fenyítőházak müködését, a XVII-XIX. század büntetés-végrehajtási fordulatait ismerhetjük meg a müből. A szerző bemutatja, hogy a fenyítőházi teória milyen változásokon ment keresztül, illetve hogy az európai fenyítőház-alapítási folyamat Magyarországon milyen fordulatokat hozott, hogyan befolyásolta a magyar büntetés-végrehajtás fejlődését. A társadalom számára hasznossá formálás, a jobbítás, a nevelés, a meggyőzés, az oktatás és a lelki gondozás céljait kitűzve egy korai „reszocializációs” gondolatot honosított meg. (F. P. P.) 
- A büntetőeljárás gyorsításáról

PÁpal-Tarr Ágnes

Gondolat Kiadó, Budapest, 2012

Monográfia. Terjedelem: 317. Bibliográfia: 303-317. ISBN 9789636934163

- A szerző egyetemi oktató, aki könyvében a büntetőeljárás egyik legégetőbb problémájára, az eljárások elhúzódására keresi a megoldást. A mű első részében az eljárások gyorsítását tárgyalja általában, érintve a kapcsolódó nemzetközi és európai követelményeket, majd a második részben a közös kontinentális hagyományokra és mégis eltérő - a legalitás, illetve az opportunitás - elvre helyezkedő magyar és francia büntetőeljárás időbeli folyamatát követve mutatja be az eljárást gyorsító intézményeket. A kötet célja nem az adott téma kommentárszerű bemutatása vagy részletes gyakorlati elemzése, hanem a legfontosabb hasonlóságok és eltérések feltárása volt, ami kölcsönösen segítheti az eljárás gyorsítását mindkét államban. (T. A. N.)

- Tanúvédelem a magyar büntetöeljárásban

SzABó Krisztián

HVG-ORAC, Budapest, 2012

Monográfia. Terjedelem: 316. Bibliográfia: 301-316. ISBN 9789632581668

- A szerző egyetemi oktató, ügyvéd, aki a tanúvédelem hazai szabályozását mutatja be a büntetőeljárásban arra tekintettel, hogy a tanúvallomás a bizonyítás során az egyik leggyakrabban igénybe vett bizonyítási eszköz, és egyben az egyik legnélkülözhetetlenebb bizonyítékforrás is. A könyv tárgyalja a tanúvédelem általános kérdéseit, és bemutatja a rendelkezésre álló büntető anyagi jogi, eljárásjogi és rendészeti eszközöket, majd specifikumként a családon belül elkövetett bűncselekmények esetén alkalmazható tanúvédelmi eszközöket. A kötet összegyüjti a strasbourgi bíróság vonatkozó ítéleteit is. (T. A. N.)

\section{EURÓPA-JOG}

- European peripheries

Andrássy György-Jyrki Käkönen-Nagy Noémi (szerk.)

University of Pécs Faculty of Law Centre for European Studies - Publikon, Pécs, 2012

(Sorozat: Studia Europaea 2012 - Jurisprudentia et Practica; 2. ISSN 2026-5049) Tanulmánykötet. Terjedelem: 221. Bibliográfia az egyes tanulmányok végén. ISBN 9786155001536

- A szerkesztők és a szerzők különböző közjogi jogterületek és kapcsolódó tudományterületek oktatói, kutatói; kötetük a pécsi és a tallinni egyetem (korábban finn és román egyetemeket is bekapcsoló) sokéves közös projektjének lezárásaként született, egy 2011-es közös nyári egyetem és konferencia anyagaiból. Az együttműködés és a kötet célja az „európai perifériákat” foglalkoztató, többféle tudományterületet (így a jogtudomány mellett a filozófiát, közgazdaság-tudományt is) 
érintő kérdések beemelése a tudományos diskurzusba. A tanulmányok így igen sokszínüek, foglalkoznak többek között a kék gazdaság és a fenntartható fejlődés problémáival, a kisebbségi jogokkal és az észt külkapcsolatokkal is. (F. F.)

- Az Európai Unió jogának alapjai

Gombos Katalin

CompLex, Budapest, 2012

Tankönyv. Terjedelem: 313. Bibliográfia a jegyzetekben.

ISBN 9789632952249971

- A szerző egyetemi oktató, gyakorló bíró. Tankönyve, amely nem csak joghallgatók számára készült, az Európai Unió működésének, szerkezetének, történetének és jövőjének bemutatására vállalkozik. Az uniós jogi tankönyvek szokásos felosztását követve külön fejezetekben tekinti át az unió történetét, majd az intézményi, jogforrási, eljárási kérdéseket, a közös politikák közül pedig a közös kül- és biztonságpolitikát, a szabadság, a biztonság és a jog érvényesülésének térségét, végül a belső piaci és a versenyjogi szabályokat. (P. Cs.)

- Az Európai Parlament a Bíróság előtt: Az Európai Unió Bírósága gyakorlatának hatása az Európai Parlament intézményi pozíciójára

MOHAY Ágoston

PTE ÁJK Európa Központ - Publikon, Pécs, 2012

(Sorozat: Studia Europaea, ISSN 2062-5049, Studia Europaea 2012 Jurisprudentia et Practica; 3.)

Kismonográfia. Terjedelem: 198. Bibliográfia: 183-190. és a jegyzetekben. ISBN 9786155001642

- A szerző egyetemi oktató, doktori disszertációja alapján készült kötete az uniós intézményi jog izgalmas témáját vizsgálja: az Európai Parlament státuszának, hatásköreinek alakulását az EU Bíróság jogértelmezési, jogfejlesztési gyakorlatának köszönhetően. Számos luxemburgi bírósági ítélet elemzésével járja körül az Európai Parlament perképességének, szervezetének, működésének és hatásköreinek alakulását a kezdetektől 2011-ig. Konklúziója, hogy az EU Bíróság esetjogát ezen a területen alapvetően meghatározza az ún. intézményi egyensúly elve, vagyis az a szándék, hogy biztosítsa az uniós intézmények egymáshoz viszonyított hatalmi egyensúlyát. (F. F.)

- Az Európai Unió joga

Mohay Ágoston-Szalayné Sándor Erzsébet (szerk.)

A 2011-ben megjelent második, átdolgozott kiadás változatlan utánnyomása. Dialóg Campus, Budapest-Pécs, 2012

(Sorozat: Dialóg Campus Szakkönyvek, ISSN 1417-7986; Jogi Szakvizsga Segédkönyvek, ISSN 1587-6659)

Tankönyv. Terjedelem: 311. Bibliográfia: 302-311. és a szövegben.

ISBN 9789639950535 (P. Cs.) 
- A Brüsszel l. rendelet reformja

Osztovits András (szerk.)

KRE ÁJK, Budapest, 2012

(Sorozat: Acta Caroliensia Conventorum Scientiarum luridico-Politicarum, ISSN 2063-4757; 2.)

Tanulmánykötet. Terjedelem: 197. Bibliográfia a jegyzetekben.

ISBN 9786155107610

- A kötet szerzői egyetemi oktatók, illetve uniós jogi területen dolgozó gyakorló jogászok. Tanulmányaikban az Európai Unión belüli igazságügyi együttműködés egyik kulcselemének számító, a polgári és kereskedelmi ügyekben a joghatóságról, illetve a határozatok elismeréséről és végrehajtásáról szóló, 2000-ben elfogadott tanácsi rendelet egyes elemeit, illetve ezek tervezett reformját járják körül. A dolgozatok érintik például a joghatósági szabályokat és a választottbírósági eljárást, de kitérnek a rendelet módosítására irányuló tárgyalásokra is. A rendelet reformjáról szóló jogszabály 2012 végén megszületett, a kötetet így különösen érdekessé teszi, hogy rálátást nyújt a módosítások hátterére és lehetőségeire. ( $F$. $F$.)

- The Foreseeable Reforms of Regulation 1/2003 Regarding the European Competition Network and the Cooperation with National Jurisdictions: 1/2003-as Rendelet előrelátható reformjai az Európai Versenyhálózattal és a nemzeti törvénykezésekkel való együttmüködés tekintetében

Rouzier, Marie-Charlotte-Kardos, Lili (szerk.)

E-press Nyomda, Szeged, 2012

(Sorozat: Az Európa-Tanulmányok Központ Füzetei, ISSN 1788-4373; 4.)

Konferenciakiadvány. Terjedelem: 100. Bibliográfia a lábjegyzetekben.

ISBN 9789638699633

- A szerzők magyar és külföldi versenyjogi szakemberek. A kiadvány a 2010 áprilisában Szegeden tartott nagyszabású versenyjogi konferencia előadásainak írásos anyagát tartalmazza. A versenyjog valamennyi érintett területét (EU Bizottság Versenypolitikai Főigazgatóság, magyar és külföldi versenyhatóságok, jogtudomány) képviselő előadók négy témakört járnak körül: az Európai Versenyhatóságok Hálózatán belüli ügyelosztást, a Bizottság és a tagállami versenyhatóságok közötti információcserét, a versenyügyi decentralizációt és a tagállami bíróságokkal való együttmüködést. (F. F.)

- The Transfer of the Company Seat within the European Union: the Impact of the Freedom of Establishment on National Laws

SzABADos, Tamás

Eötvös University Press, Budapest, 2012

(Sorozat: ELTE Jogi Kari Tudomány, ISSN 2060-9361; 20.)

Monográfia. Terjedelem: 249. Bibliográfia: 211-234. és a jegyzetekben. ISBN 9789633121443

- A szerző egyetemi oktató. Doktori disszertációja alapján készült kötete az uniós belső piaci jog fontos kérdését vizsgálja: a vállalkozások székhelyáthelyezésének szabályait és joggyakorlatát az uniós jogban és számos tagállam nemzeti jogá- 
ban. A téma megközelítése sajátos: az uniós jog nemzeti jogrendszerekre gyakorolt hatását vizsgálja a vállalkozás szabadsága témakörében. Ennek megfelelően a vállalkozás szabadságára vonatkozó uniós követelmények mellett kitér az uniós és nemzeti jogrendszerek általános kapcsolódási pontjaira is. A könyv második felében vizsgálja az egyes tagállamok (Magyarország és öt nyugati tagállam) belső jogi előírásainak változását az uniós jog fényében. A vizsgálat az uniós és a tagállami bírósági esetjogra is kiterjed. (F. F.)

- Bevezetés az európai uniós támogatások rendszerébe

SzABÓ Zsolt

Patrocinium, Budapest, 2012

(Sorozat: Wesselényi-sorozat)

Kézikönyv. Terjedelem: 221. Bibliográfia nincs. ISBN 9786155107757

- A szerző egyetemi oktató. Kötete az EU 2007-2013 közötti költségvetési időszakára vonatkozóan a Strukturális Alapokból nyújtott támogatások felhasználásának uniós és hazai szabályozásával foglalkozik. Kitér a támogatást igénylőkre és a támogatást nyújtókra vonatkozó szabályokra, illetve a támogatások felhasználását meghatározó uniós politikákra is. A kohéziós és más kapcsolódó EU-s politikák bemutatása mellett külön fejezetek foglalkoznak a fejlesztéspolitika magyarországi intézményrendszerével, a pályázati rendszerrel, a pénzügyi lebonyolítással, az ellenőrzéssel és a pénzügyi szankciókkal. (F. F.)

- Az Európai Unió fejlődésének alapismeretei

SzÉKELY Klára

Savaria University Press, Szombathely, 2012

Ismeretterjesztő jegyzet. Terjedelem: 133. Bibliográfia: 130.

ISBN 97896398829420

- A szerző egyetemi oktató. A kötet egy uniós pályázat keretében készült, amelynek célja, hogy a közoktatásban részt vevő oktatók számára biztosítsa a legújabb európai uniós ismereteket, illetve segítséget nyújtson ezek átadásához. Ennek megfelelően a jegyzetben az Európai Unió müködéséhez kapcsolódó legalapvetőbb információkat (történet, jogrend, intézmények, Magyarország csatlakozása) számos, a megértést könnyítő táblázat és folyamatábra, valamint az ismeretanyag továbbadását segítő gyakorlati tanács egészíti ki. Az ismeretek elsajátítását a jegyzet végén elhelyezett fogalomtár is segíti. A szöveg elektronikusan is elérhető a Nyugat-magyarországi Egyetem honlapján keresztül. (P. Cs.)

- Az európai uniós jogfejlődés irányai a Lisszaboni Szerződés után: válogatott tanulmányok

Vörös Imre-Horváthy Balázs (szerk.)

HVG-ORAC, Budapest, 2012

Tanulmánykötet. Terjedelem: 192. Bibliográfia az egyes fejezetek végén és a jegyzetekben. ISBN 9789632581736

- A tanulmányok szerzői az MTA JTI-hez kötődő jogász kutatók. A dolgozatok az intézet által „A Lisszaboni Szerződés hatása a magyar jogrendszerre” címen foly- 
tatott többéves kutatási projekt keretében készültek, a kutatás föbb irányainak bemutatása és a főbb eredmények kiemelése céljával. Ennek megfelelően az írások igen sokszínűek. Foglalkoznak többek között a hatáskörök rendezésének kérdésével (Fekete Balázs), az alapszerződések módosításának szabályaival (Vincze Attila), az uniós alapjogok horizontális hatályával (Gárdos-Orosz Fruzsina), az EU nemzetközi magánjogával (Czigler Dezső Tamás), a túlzotthiány-eljárással (Kreisz Brigitta) és a közös kereskedelempolitikával (Horváthy Balázs) is. (F. F.)

- Az európai családjog kézikönyve: házassággal, szülői felelősséggel és tartással kapcsolatos ügyek szabályozása az európai uniós jogban és hágai egyezményekben

WOPERA Zsuzsa

HVG-ORAC, Budapest, 2012

Kézikönyv. Terjedelem: 341. Bibliográfia: 328-334. és a jegyzetekben. ISBN 9789632581606

- A szerző egyetemi oktató. Kötete átfogóan ismerteti a határokon átnyúló családjogi ügyekre vonatkozó uniós és nemzetközi jogforrásokat és bírósági esetjogot, kitérve a magyar szabályozás bemutatására is. Így külön fejezet foglalkozik a házassági és szülői felelősséggel kapcsolatos ügyekre vonatkozó ún. Brüsszel II. rendelettel, a házasság felbontására vonatkozó ún. Róma III. rendelettel, a tartási ügyekre vonatkozó rendeletekkel, illetve a házasság és a bejegyzett élettársi közösség vagyonjogi következményeivel kapcsolatos két bizottsági jogalkotási javaslattal - ezek jogalkotási eljárása jelenleg is folyamatban van. (F. F.)

\section{JOGTÖRTÉNET, JOGBÖLCSELET}

- Mert az Ördög velem volt: Élet elleni büncselekmények a 19. század első felében. Bató Szilvia

L'Harmattan, Budapest, 2012 Monográfia. Terjedelem: 324. Bibliográfia: 234-256. ISBN 9789632366074

- A szerző Bolyai-ösztöníjas kutató a Szegedi Tudományegyetem Állam- és Jogtudományi Karán. Kötetében a 19. századi Magyarország élet elleni cselekményeit vizsgálja a tudományos munkákon és a jogszabályokon túl bőséges levéltári irodalomra támaszkodva. A 18. és 19. századi magyar büntetőjog jellegzetességeiből kiindulva a szerző a korszak szabályozási rendszereinek sajátosságait kutatva jut el az emberölés különböző eseteinek tárgyalásához. A kötet ezután az emberölés minősített változataival foglalkozik, mint a rokongyilkosság, különleges jogállású személy megölése, a „megétetés”, bér-, rabló-, álnok-, csecsemőgyilkosság, magzatelhajtás, gyermekkitétel. A jobb megértést és eligazodást 900 lábjegyzet és 11 táblázat segíti. Ajánlott minden büntetőjog és jogtörténet iránt érdeklődő olvasónak, akik ezzel az eddig kevésbé kutatott témakörrel ismerkednének meg behatóbban. (L. N.) 
- A jogrendszerek világa

Badó Attila-Bencze Mátyás-Bóka János-Mezei Péter (szerk.)

Pro Talentis Universitatis Alapítvány, Szeged, 2012

Tankönyv. Terjedelem: 320. Bibliográfia a lábjegyzetekben.

ISBN 9789630850698

- A szerzők egyetemi oktatók, kutatók. A tankönyv a világ nagy jogrendszereinek bemutatását tűzi ki célul, ennek keretében az egyes jogrendszerek kulturális hátterét, szerkezetét, müködési sajátosságait ismerteti. A mú áttekinti a jogrendszerek csoportosításának lehetséges módozatait, ezenkívül betekintést nyújt például az angolszász, a német, a francia, a skandináv, a kínai, a japán és az iszlám jog világába. A tankönyv elsősorban az összehasonlító jog mint tárgy oktatásához, illetőleg elsajátításához nyújt segédletet, de a joghallgatók és jogászok mellett a nagy jogi kultúrák jellemző jegyei iránt érdeklődők is haszonnal forgathatják. (Zs. Zs.)

- Jogszociológiai előadások

Bencze Mátyás-Vinnai Edina (szerk.)

Debreceni Egyetemi Kiadó, Debrecen University Press, Debrecen, 2012

Tankönyv. Terjedelem: 173. Bibliográfia a lábjegyzetekben.

ISBN 9789633182932

- A szerzők egyetemi oktatók, akik elsősorban a joggyakorlat jogszociológiának területén folytatnak intenzív kutatásokat. A tankönyv a kutatások eredményére építve a jogszociológia számos kérdéskörét megvizsgálja, illetőleg áttekint jó néhány joggal kapcsolatos (társadalmi) jelenséget, összefüggést, amely hatással van a jog múködésére. A kötet a jogszociológiával kapcsolatos elméleti megalapozást követően - amelyben bemutatja, hogy mi is a jogszociológia, és hogy mivel foglalkozik - olyan kérdéseket tárgyal, mint a jogalkalmazási folyamat, a bírói ténymegállapítás és a büntetéskiszabási gyakorlat szociológiája, ezenkívül kitér a professzionális jogalkalmazás alternatíváira, a laikusok joghoz való viszonyára, valamint a jogászképzés, illetőleg a globalizáció és a jog kapcsolatának aktuális kérdéseibe is bepillantást nyújt. (Zs. Zs.)

- Metszetek a jogásztársadalomról

NAGY Zsolt

Pólay Elemér Alapítvány, Szeged, 2012

Monográfia. Terjedelem: 147. Bibliográfia: 137-147. és a lábjegyzetekben. ISBN 9789639650923

- A szerző egyetemi oktató, kutató. A hét fejezetre tagolódó könyvben a jogászi hivatás egyes sajátosságainak jogszociológiai szemléletű elemzését olvashatjuk. A mú áttekintést nyújt a jogászi professzió történeti fejlődéséröl, bemutatja a jog és a jogászi hivatás presztízsének növekedési folyamatát, megvizsgálja a jogi oktatás és a gyakorló jogászok közötti kapcsolat egyes kérdéseit, ezeken kívül foglalkozik a jogászság jövőjével, a globalizáció jogászi hivatásra gyakorolt hatásával, továbbá a jogásztársadalmat érintő kihívásokkal és változásokkal. A könyv hézagpótló 
jellegủ, hiszen a magyar jogtudomány az utóbbi időben kevés figyelmet fordított a jogászságot érő hatások tudományos vizsgálatára. A kötet a jogszociológia kutatói mellett a jogászi hivatás jellegzetességei iránt érdeklődő, esetlegesen nem szakmabeliek figyelmére is számot tarthat. (Zs. Zs.)

\section{- Jog és Társadalom a Lex Baiuvariorumban}

NótÁRI Tamás

LecTum Kiadó, Szeged, 2012

Monográfia. Terjedelem: 410. Bibliográfia: 371-405. ISBN 9789639640405

- A szerző egyetemi oktató. Monográfiájában a kora középkori Bajorország legfontosabb jogtörténeti forrását, a Lex Baiuvariorumot elemzi négy fejezetben. Először Bajorország történelmét és társadalmát, majd a Lex Baiuvariorum datálását tekinti át, részletesen kitérve a történelem és a jog összefüggéseire, valamint az egyes jogterületekre a magánjogtól a büntetőjogig. A harmadik rész speciálisan a rabszolgákkal foglalkozik, végül a törvény nyelvezetét, forrásait és hatását ismerhetjük meg az alemann, frank és egyéb germán jogokra vonatkozóan. Számunkra különösen fontos Szent István törvényeire gyakorolt hatása. A kötet végén gazdag szakirodalom található, melyek nagy része latin és német nyelvü. (L. N.)

- Iustinianus császár egyházpolitikai rendelkezései

SÁrY Pál

Szent István Társulat, az Apostoli Szentszék Könyvkiadója, Budapest, 2012 Monográfia. Terjedelem: 320. Forrásmutató: 289-303. Szakirodalmi rövidítések: 304. Bibliográfia: 305-320. ISBN 9789632773285

- A szerző egyetemi oktató. Munkája hiánypótló, mivel lustinianus császárral a jogés egyháztörténet, valamint a római jog is főként kodifikációja tekintetében foglalkozik. A császár azonban mindemellett óriási jogalkotó-jogfejlesztő tevékenységet is végzett. A kötet négy részben foglalkozik lustinianus rendelkezéseivel az egyházpolitika terén. Az első rész az egyházpolitikai akciókat és hitelvi rendelkezéseket, a második az egyházszervezet és müködés szabályozását tartalmazza a püspököktől az alsóbb papságig, az ünnepektől a szertartásokig. A harmadik rész a „kívülállók”, eretnekek, zsidók, pogányok és szamaritánusok jogait, főként azok korlátozásait tárgyalja, végül pedig a keresztény értékrend és szellemiség erősítésére tett rendelkezések következnek (nők, gyermekek, rabszolgák, felszabadítottak támogatása, adósok védelme, a házasság szabályozása és a nemi erkölcs védelme). A kötet végén részletes forrásmutató és bibliográfia található. (L. N.)

\section{- Bünvádi eljárások az Újszövetségben}

SÁRY Pál

Negyedik kiadás. Szent István Társulat, Budapest, 2012

Monográfia. Terjedelem: 240. Bibliográfia: 225-240. ISBN 9789633616291

- A szerző egyetemi oktatóként Jézus pere és Szent Pál ellen lefolytatott eljárások teológiai, valamint jog- és irodalomtörténeti szempontú bemutatására törekszik elsősorban a fellelhető néhány korabeli forrás elemzésével és azok modern 
értelmezésével. Jogi szaktudása és teológiai jártassága révén a perek szakmai elemzését és jogi rekonstrukcióját végzi el, melynek során megelevenednek az evangéliumi események történelmi környezetbe ágyazva. A negyedik kiadást nem csak a kötet sikere motiválta, mert a szerző az első kiadásához képest további részleteket tár az olvasók elé. A kutatás alaposságát igazolja a mú végén található részletes bibliográfia és a felhasznált ókori források magyar nyelvű forrásjegyzéke. (T. A. N.)

- Multidiszciplináris jogi tanulmányok

SzMODIs Jenö

Bíbor Kiadó, Miskolc, 2012

Monográfia. Terjedelem: 234. Bibliográfia: 205-228. és a lábjegyzetekben. ISBN 9789639634446

- A szerző egyetemi oktató, kutató. A könyv a jog jelenségvilágának vizsgálatát újító szándékkal, multidiszciplináris módon közelíti meg, ennek keretében bemutatja a jog multidiszciplináris kutatásának eddigi irányvonalait és gyakorlatát, valamint áttekinti az esetleges további vizsgálódási lehetőségét is. Ennek során a jog és más tudományágak közötti kapcsolódási pontokat, illetve összefüggéseket keresi meg és vázolja fel, így bemutatja olyan tudományterületeknek, mint a filozófia, etika, teológia, történelem, szociológia, irodalom, kultúrantropológia, pszichológia, kultúra és gazdaság joggal való összefüggéseit. Ezeken kívül a humánetológia, a szociálpszichológia, a személyiségpszichológia, a vallástörténet, illetőleg a történelemfilozófia és a jog közötti, kevésbé hagyományosnak tekinthető kapcsolódási pontokat is számba veszi. A mủ egyik nem titkolt célja, hogy előmozdítsa a joggal kapcsolatos kutatások perspektívájának szélesedését. (Zs. Zs.)

\section{KÖZIGAZGATÁSI JOG}

- Helyi önkormányzatok

Árva Zsuzsanna-BalÁzs István-Balla Zsuzsa-BArta Attila-Veszprémı Bernadett 2., átdolgozott kiadás, Debreceni Egyetemi Kiadó, Debrecen, 2012

Tankönyv. Terjedelem 315. Bibliográfia a lábjegyzetekben és fejezetenként. ISBN 9789633182741

- A szerzők egyetemi oktatók. A kötet tankönyvként készült az igazgatásszervező (közigazgatás-szervező) képzésben részt vevő hallgatók képzésében, az azonos nevű tárgy oktatásához. A könyv átdolgozására a 2011-ben megjelent első kiadás után azért volt szükség, mivel az alkotmányos fordulatot követően az Országgyülés elfogadta a Magyarország helyi önkormányzatairól szóló 2011. évi CLXXXIX. törvényt. A tankönyv a törvény rendelkezéseit és a 2012-ben már rendelkezésre álló más jogszabályokat dolgozza fel, a tárgy keretében tartott előadások tematikáját követve. (P. O.) 
- Közigazgatás-elmélet

ÁrVA Zsuzsanna-BaLÁzs István-BARTA Attila-Veszprémı Bernadett

2., átdolgozott kiadás. Debreceni Egyetemi Kiadó, Debrecen, 2012

Egyetemi tankönyv. Terjedelem: 299. Bibliográfia a fejezetek végén.

ISBN 9789633182741

- A tankönyv második kiadása szerkezetileg túlnyomórészt megegyezik a 2011-ben megjelent első kiadással, tartalmilag viszont a szerzők a jogszabályi változásokra tekintettel hatályosították a kötetet. Ennek megfelelően átdolgozásra, részletesebb kifejtésre került két fejezet, nevezetesen a közigazgatás intézményrendszere és a közigazgatás személyzete. (P. O.)

- A közigazgatási hatósági eljárás és szolgáltatás általános szabályai Balla Zoltán-BuzÁs Gábor-RIxer Ádám-SzILvásy György Péter Rejtjel Kiadó, Budapest, 2012 3., átdolgozott, kiegészített kiadás. Terjedelem: 262. Bibliográfia: 261-262. ISBN 978-963-7255-82-3

- A szerzők egyetemi oktatók. A közigazgatási eljárás sajátossága az állandó változás, a megújuló társadalmi viszonyokhoz alkalmazkodás és a jogi keretek ezekhez való igazítása. Ez az indoka annak, hogy a kötet már a 3. kiadásban jelenik meg. A szerzők a Ket. felépítését követik, de a tanulhatóságot szem előtt tartva. Minden oldal szélén az adott bekezdés, tartalom legfontosabb címszavai szerepelnek, jól tagolt, a kiemelt szövegrészek segítenek a lényeg megvilágításában. Elmélet és gyakorlat egyszerre jelen van, hiszen a jogszabályszöveg mellett fogalommeghatározásokat is találunk. (V. B.)

- Közigazgatás-technológia

Czékman Zsolt-ToRma András

Miskolci Egyetemi Kiadó, Miskolc, 2012

Terjedelem: 142. Bibliográfia: 137-142. ISBN 978-615-5216-08-4

- A szerzők egyetemi oktatók. Az információs társadalom korában elengedhetetlen az informatika és a jog közötti kapcsolatteremtés és a technika lehetőségeinek felhasználása a közigazgatásban. A szerzők ennek elméleti megalapozására törekednek (az állam és a közigazgatás működésének egyes kérdései, a közigazgatás működési folyamatai, a munkafolyamatok racionalizálása, szervezése témakörében) és jogi alapjaival (az ügyiratkezelési technológia hatósági szabályozásával), informatikai vonatkozásaival (a közigazgatási munkafolyamatok technikai támogatásával) foglalkoznak. (V. B.)

- A közigazgatási jog alapjai

FEKETE Orsolya

2., átdolgozott és bővített kiadás. Pólay Elemér Alapítvány, Szeged, 2012

(Sorozat: A Pólay Elemér Alapítvány Tansegédletei, ISSN 1786-3554)

Jegyzet. Terjedelem: 269. Bibliográfia: 267-269. ISBN 9789639650930 
- A szerző egyetemi oktató, jegyzete az első, 2010-ben megjelent kiadás átdolgozott, bővített változata. A szerző a hatályos joganyagnak megfelelően aktualizálta a kötetet, különös tekintettel a közigazgatás szervezetére vonatkozó jogszabályi változásokra, illetve több egyéb elemmel is bővítette azt, tárgyalva a közigazgatás helyét az államhatalmi ágak viszonyrendszerében, a nemzetközi jogi szabályok mint a közigazgatási jog forrásai témakört, illetve a közigazgatási hatósági eljárással kapcsolatos néhány, a korábbi kiadásban még nem szereplő jogintézményt, így az egyszerúsített jegyzőkönyvet, az elveszett, megsemmisült iratok pótlását és a hatósági döntés jogerejét. (P. O.)

- A rendészettudomány határkövei. „Tanulmányok a Pécsi Határör Tudományos Közlemények első évtizedéből"

Gaál Gyula-Hautzinger Zoltán (szerk.)

Magyar Hadtudományi Társaság Határőr Szakosztály Pécsi Szakcsoportja, Pécs, 2012

Tanulmánykötet. Terjedelem: 318. Bibliográfia a tanulmányok végén és/vagy lábjegyzetekben. ISBN 9789630841122

- A tanulmánykötet konferencia-előadások olyan írásos változataiból válogat, melyek a Pécsi Határőr Tudományos Közleményekben jelentek meg az elmúlt tíz évben. A tanulmányok az esetek többségében átdolgozott formában kerültek a kötetbe. A kötet szemléletmódja sokszínú, hiszen szerzőik között egyaránt megtalálhatók a rendészettudomány képviselői, jogi, katonai, katasztrófavédelmi kutatók, valamint gyakorlati határrendészeti szakemberek. Az írásokat négy fejezetbe rendezték a szerkesztők: a rendészetelmélet, a rendészetszervezet és a nemzetközi vonatkozások mellett a rendészettudomány periferikus területei is helyet kaptak. Ez utóbbi fejezetben olvasható többek között egy közigazgatási jogi nézőpontból közelítő tanulmány, illetve egy, a bűnözés etikai hátterével foglalkozó írás. A tanulmánykötet betekintést ad például a rendészet aktuális tudományos megközelítéseibe, alkotmányos alapjaiba, szervezeti és személyzeti kérdéseibe, a határrendészeti feladatellátásba, valamint a schengeni integráció történetébe és jelentőségébe. (P. O.)

- Sodorvonalon. Tanulmányok Virányi Gergely 60. születésnapja tiszteletére Hautzinger Zoltán-Verhóczki János (szerk.)

Magyar Rendészettudományi Társaság Határrendészeti Tagozat, Budapest, 2012 Tanulmánykötet. Terjedelem: 376. Bibliográfia: 373-376. és lábjegyzetekben, illetve egyes tanulmányok végén. ISBN 9789630832711

- A szerzők egyetemi oktatók, kutatók, tanulmánykötetük Virányi Gergely nyugállományú határőr dandártábornok, főiskolai tanár tiszteletére készült. A tudományos írások mellett találunk benne személyes hangvételüt is. $A$ tanulmányok változatos témákat érintenek, többek között a rendőrség szerepét, müködését és személyi állományát, az erőszak történeti vonatkozásait, a nemzetbiztonsági igazgatást, a terrorizmust, a határrendészetet, a schengeni integrációt, a migrációt, a kriminológia prioritásait, az erőszakos bűnözés etiológiáját, illetve a kriminálpedagógiát. Több írás foglalkozik az oktatás, képzés intézményi és tar- 
talmi kérdéseivel (katasztrófavédelmi képzés, katonai jogi képzés, rendőrtisztképzés, határrendészeti képzés, a Nemzeti Közszolgálati Egyetem megalakulása, az Európai Rendőrakadémia jövője stb.). A kötet a rendeszet.hu internetes oldalon is elérhető. (P. O.)

\section{- Közigazgatási büntetőjog}

Jacsó Judit-SÁNTHA Ferenc

Debreceni Egyetemi Kiadó, Miskolc, 2012, 2., átdolgozott kiadás

Egyetemi jegyzet. Terjedelem: 158. Bibliográfia: 157-158. ISBN 9786155216343

- A szerzők egyetemi oktatók. A kötet az azonos nevű tárgy oktatási segédanyagaként szolgál. A közigazgatási büntetőjog és igazságügyi büntetőjog közötti megkülönböztetés James Goldschmidt 1902-es monográfiáiától kezdve létezik a kontinentális jogtudományokban, különös tekintettel a német és a magyar jogra. A könyv a szabálysértési jog intézményeit dolgozza fel a 2012. évi II. törvény rendelkezéseit követve, így egy rövid dogmatikai alapozás után foglalkozik a szabálysértési jog fogalmával, általános anyagi jogi intézményeivel és az eljárás alapvető szabályaival, amelynek során kitér egyes kapcsolódó büntetőjogi jellegü szabályokra is. (Á. Zs.)

- Közigazgatási hatósági eljárás

Kalas Tibor (szerk.)

Átdolgozott kiadás. Miskolci Egyetemi Kiadó, Miskolc, 2012

Egyetemi jegyzet. Terjedelem: 175. Bibliográfia: 173-175. ISBN 9789636619831

- A szerzők egyetemi oktatók, kötetük tananyagként szolgál. Elméleti szempontból mutatja be a közigazgatási hatósági eljárás alapvető szabályait. Az előző kiadás átdolgozására a Ket. 2012-es átfogó módosítása adott okot. Az eljárás rendszerben való elhelyezése végett foglalkozik a közigazgatási cselekményekkel, alapfogalmakkal, az eljárás tagozódásával, és a törvény felépítésének megfelelően taglalja az alapelveket, elsőfokú eljárást, döntésfajtákat, jogorvoslati eszközöket, a döntés-felülvizsgálat eseteit és a végrehajtási eljárás szabályait. (V. B.)

- Bevezetés az anyakönyvi igazgatásba

LAMPÉRT Bernadett

2., javított kiadás, SL és Tsa Bt., Telki, 2012

Tansegédlet. Terjedelem: 243. Bibliográfia nincs. ISBN 9789638920812

- A szerző megyei anyakönyvi felügyelö. A tankönyv az anyakönyvi szakvizsgára készülők tanulását kívánja segíteni azzal, hogy egy hiánypótló kötetben foglalja össze az ágazat legfontosabb szabályait. Az alapfogalmak és az anyakönyvi igazgatás történetének bemutatása mellett összegyűjti a kapcsolódó jogszabályokat, ismerteti a közigazgatási hatósági eljárás általános szabályait, a legalapvetőbb polgári jogi fogalmakat (jogképesség, cselekvőképesség, törvényes képviselet). Foglalkozik az adatvédelem, nemzetközi magánjog kérdéseivel. Meghatározza az anyakönyvvezető feladatait és az egyes élethelyzeteket (születés, házasság, élettársi kapcsolat, halál) áttekintve feldolgozza az anyakönyvezés szabályait (iratkezelés, adatszolgáltatás, illeték, díj, ASZA). (V. B.) 
- Közigazgatási ügyvitel

Melczer Krisztina

Átdolgozott, hatályosított 3. kiadás. PTE ÁJK, Pécs, 2012

Terjedelem: 204. Bibliográfia: 203. ISBN 9636420823

- A szerző egyetemi oktató. A kötet nem a közigazgatási hatósági eljárás bemutatására, hanem általában a közigazgatási szervek munkájának bemutatására törekszik, ami több, mint az eljárás. Ismerteti a közigazgatás felépítésére és a benne dolgozók jogviszonyára vonatkozó hatályos szabályokat, bemutatja a közigazgatási eljárás szabályozását, részletesen foglalkozik az ügyvitel feladatrendszerével és az ügyiratkezelés jogi hátterének felvázolásával. Ez utóbbi az adatvédelem (személyes adatok védelme, közérdekü adatok nyilvánossága, információs önrendelkezési jog) és a titokvédelem témaköreinek megemlítését is igényli. Jól tagolt, a kapcsolódó jogszabály szövege, annak magyarázata, fogalomtár segíti az ismeretek elsajátítását. Nem utolsósorban a gyakorlati oldal megvilágítására iratmintákat is tartalmaz a kötet. (V. B.)

- A jó állam aspektusai, perspektívái. Az önkormányzatok változó gazdasági, jogi környezete

Papp Tekla (szerk.)

Pólay Elemér Alapítvány, Szeged, 2012

Sorozat: Lectiones luridicae, ISSN 2062-5588

Konferenciakiadvány. Terjedelem: 143. Bibliográfia a lábjegyzetekben és az egyes tanulmányok végén. ISBN 9786155300004

- A szerző egyetemi oktató. A kiadvány az MTA Szegedi Akadémiai Bizottság Jogi Szakbizottságának Gazdasági Jogi Munkabizottsága és a Europe Direct Szeged által 2012. április 26-án megrendezett tudományos konferencia előadásainak nagy részét tartalmazza. „Az önkormányzatok változó gazdasági, jogi környezete és a jó állam aspektusai, perspektívái" című konferencia felszólalói között a jogász és közgazdász szakemberek mellett a Juhász Gyula Pedagógusképző Kar oktatói, kutatói is megtalálhatóak, ami a kiadvány tematikai sokszínűségében is visszatükröződik. A feldolgozott témák között szóba kerül pl. az önkormányzati rendszer átalakulásának iránya, a járási rendszer bevezetése, az e-közigazgatás, a közszféra, valamint a közszolgálati szerződések kérdésköre. (B. A.)

- Felelősség a közszolgálatban

VESZPRÉmı Bernadett

Debreceni Egyetemi Kiadó, Debrecen, 2012

Egyetemi jegyzet. Terjedelem: 139. Bibliográfia: 127-139. ISBN 9789633181768

- A szerző egyetemi oktató. Kiindulópontja, hogy hatékony közigazgatás elképzelhetetlen megfelelő munkaerő nélkül. Bár a szerző elsősorban a közszolgálat (köz-, illetve kormánytisztviselök) felelősségi rendszerének bemutatására fókuszál, munkája ettől általánosabb áttekintést ad a tisztviselőkre vonatkozó szabályokról. A közszolgálat fogalmának meghatározásán, valamint az egyes közszolgálati rendszerek bemutatását követöen a tankönyv külön taglalja a felelősség általános, majd közszolgálat-specifikus alakzatát. A kiadványt összegzés és de 
lege ferenda javaslatok zárják. A munkát, annak interdiszciplináris jellege miatt a jogász és igazgatásszervező szakos hallgatók mellett a közigazgatás személyi állománya iránt érdeklődők is bátran forgathatják. (B. A.)

\section{KÖRNYEZETJOG}

- Fenntartható és zöld közbeszerzés a gyakorlatban: fenntarthatóság, innováció, szociális szempontok, KKV-védelem

BaKony József-BARna Orsolya-Havas-Kovács Gabriella

Perfect, Budapest, 2012

Kézikönyv. Terjedelem: 119. Bibliográfia: 118-119. ISBN 9789633948187

- A szerzők egyetemi oktatók, könyvük négy fejezetből és a függelékből áll. Célja az információ bővítése a zöld közbeszerzéssel kapcsolatban, amely régóta jelen van az EU-tagállamokban. Ma már egyértelmü, hogy amennyiben az ajánlattevők nem alkalmazkodnak a környezetvédelmi követelményekhez, az hátrányosan érinti a versenyképességüket. A könyv középpontjában a közösségi jog és a magyar közbeszerzési törvény környezetvédelmi előírásai állnak, elsősorban a fenntarthatóságot szem előtt tartva, továbbá néhány ágazati vonatkozásra (pl. a termékdíjra) is kitérve. Számos példa és táblázat segíti a téma megértését. (B. Á.)

- Jogtudományi tanulmányok a fenntartható természeti erőforrások témakörében Csák Csilla (szerk.)

Miskolci Egyetem, Miskolc, 2012

Tanulmánykötet. Terjedelem: 203. Bibliográfia a lábjegyzetekben. ISBN 9789633580318

- A szerzők egyetemi oktatók, valamint gyakorlati szakemberek. A kötet a 2012. október 12-én, Miskolcon megrendezett „Fenntartható természeti erőforrások” címú konferencián elhangzott előadások hátterét jelentő tanulmányokat tartalmazza. A kiadvány sokszínűségét adja az a tény, hogy a természeti erőforrások jogi szabályozását több megközelítésböl vizsgálja, így köz- és magánjogi, valamint nemzetközi, európai uniós, polgári jogi, pénzügyi jogi, továbbá alkotmányjogi és jogtörténeti szempontokból, figyelembe véve az elméleti kereteket és a gyakorlatot is. A kötetben találhatunk pl. felelősségi kérdésekkel, bányászattal, génmódosítással, hulladékkal, az egészséges környezethez való joggal, a vízzel, valamint a fenntartható földhasználattal foglalkozó tanulmányokat. (Gy. A. Cs.)

- Környezetvédelmi jog és igazgatás

Fodor László

Debreceni Egyetemi Kiadó, Debrecen, 2012

Egyetemi jegyzet. Terjedelem: 174. Bibliográfia a 174. oldalon.

ISBN 9789633182895

- A szerző egyetemi oktató. A nem jogász szakos hallgatóknak szánt és a környezetvédelmi igazgatásra koncentráló tananyag könnyebb elsajátítását kiemelés segíti, míg a magyarázó szövegelemeket a szerző kisebb betűmérettel szedte. 
Az egyes fejezetek végén önellenőrző kérdéssor található. Az alapozó, elméleti fejezetek a környezetjog alapfogalmaira, rendszerére, forrásaira, valamint a szabályozás módszertanára térnek ki. Az általános részi fejezetek többek között az alapelveket, az engedélyezés rendszerét, valamint a környezeti hatásvizsgálatokat tekinti át. A különös rész körében pedig a föld-, a víz-, a levegő-, a természetvédelem, valamint a hulladékgazdálkodás szabályanyagaival ismerkedhetünk meg. A kötetet az ajánlott, magyar nyelvű irodalomjegyzék zárja. (Gy. A. Cs.)

- Geothermal Resource Asessment of the Drava Basin

Horváth Ferenc-Pap Norbert-Reményi Péter-Tóth Tamás (szerk.)

Publikon, Pécs, 2012

Monográfia. Terjedelem: 222. Bibliográfia a fejezetek végén.

ISBN 9786155001598

- A szerzők egyetemi oktatók és gyakorlati szakemberek. A könyv a MagyarországHorvátország IPA Határon Átnyúló Együttműködési Program 2007-2013 keretében készült el és a középpontjában a Dráva-medence Magyarországot és Horvátországot egyaránt érintő földtani, hidrogeológiai és geotermális viszonyainak leírása található, amelyet az ehhez a területhez kapcsolódó gazdasági és településfejlesztési háttér bemutatása követ. Végezetül pedig a geotermikus energiára vonatkozó magyar, horvát és EU-s jogszabályok kerülnek bemutatásra. A könyvet a kutatás eredményeit bemutató, korábban nem publikált térképek színesítik és teszik érthetővé a laikusok számára is. (B. Á.)

- Az Európai Unió környezeti joga

KRÄMER, Ludvig

Horváth Zsuzsanna (ford.)

Dialóg Campus Kiadó, Budapest-Pécs, 2012

Kézikönyv. Terjedelem: 464. Bibliográfia a lábjegyzetekben és a 439-447. oldalakon. ISBN 9789639950795

- A szerző oktató, kutató, az Európai Bizottság Környezeti Főigazgatóságának volt vezető tisztviselője. A kötet az „EU Environmental Law” címmel 2011 augusztusában megjelent mű (7., bővített, átdolgozott kiadás, Sweet \& Maxwell Kiadó, London) magyarra fordítása. Bemutatja az uniós környezeti politika és jog kialakulását, fejlődését, elemzi az alapító szerződések környezeti rendelkezéseit, és teljes körủen átfogja a másodlagos joganyagot. A jogesetmutató, a jogszabálymutató és a nemzetközi szerződések listája az uniós környezeti politikában, míg a kötet végén található tárgymutató a kötetben való könnyebb eligazodást teszi lehetővé. (Gy. A. Cs.)

- A települési hulladékgazdálkodás válsága - „A válság vesztesei - a paragrafusok fogságában" projekt

Litkey-Juhász Orsolya-Trombitás Gábor (szerk.)

Alapvető Jogok Biztosának Hivatala, Budapest, 2012

Konferenciakiadvány. Terjedelem: 181. Bibliográfia a lábjegyzetekben.

ISBN 9789638968203 
- A szerzők oktatók, valamint szakemberek. A kötet az alapvető jogok biztosának kiadványa a 2012. június 1-jén az Alapvető Jogok Biztosának Hivatalában tartott konferenciáról. A konferencia és a kapcsolódó kötet alapja „A válság vesztesei a paragrafusok" projekt (2012-2013), melynek célja a megújuló energiaforrások alkalmazásával kapcsolatos kérdések vizsgálata, amelybe szorosan illeszkedik a hulladékgazdálkodás területének áttekintése, visszásságainak feltérképezése. A kötet három fö eleme a konferencián elhangzott előadások, valamint hozzászólások és a kapcsolódó tanulmányok fejezetei, amelyekben többek között a települési hulladékok, a közszolgáltatók és az ösztönző rendszer szabályozási anomáliáival foglalkozó tanulmányokat olvashatunk. A kötet a hulladékról szóló, időközben elfogadott és hatályba lépett 2012. évi CLXXXV. törvény előírásaival még mint tervezettel foglalkozik. (Gy. A. Cs.)

- Oktatási anyag: oktatási anyag a zöld gazdaság kialakításához

Lükő István (szerk.)

Pécsi Tudományegyetem, Pécs, 2012

Tananyag. Terjedelem: 131. Bibliográfia a fejezetek végén.

ISBN 9789636424886

- A szerzők egyetemi oktatók. A kötet a Szlovénia-Magyarország Határon Átnyúló Együttmüködési Program 2007-2013 nemzetközi projekt egyik részterületét, a magyar környezeti design támogatási rendszereit dolgozza fel. A szerzők kilenc fejezetben tárgyalják a témát, a környezetmenedzsmenthez tartozó alapvető fogalmak magyarázatával indítanak, majd a környezetpolitika és a jog kerül a vizsgálat középpontjába. Az elemzés tárgyát képezi továbbá az EU-s és nemzeti standardok, szabványok, valamint a különböző támogatások, mint az R\&D, az eco-design és az innováció, továbbá a vállalatokhoz, illetve az eco-üzletekhez kapcsolódó támogatások bemutatása, végezetül pedig a piac szerepének az ismertetésére kerül sor. Az anyag megértését számos ábra és példa is segíti. (B. Á.)

- A környezet nemzetközi jogi védelme

MAJTÉNYı Balázs

ELTE Eötvös Kiadó, Budapest, 2012 Jegyzet. Terjedelem: 93. Bibliográfia a lábjegyzetben. ISBN 9789633120897

- A szerző egyetemi oktató; célja, hogy a felsőoktatásban tanuló alap- és mesterszakos hallgatók számára betekintést nyújtson a nemzetközi környezetvédelmi jogba. Hat fejezetben dolgozza fel a témát, amelyek elsősorban a nemzetközi környezetvédelmi jog létrejöttére, forrásaira, szereplőire, alanyaira és tárgyaira koncentrálnak, de megtalálható az egészséges környezethez való jog elemzése is. Két szervezet, nevezetesen az ENSZ és az Európa Tanács környezetvédelmi tevékenysége kerül részletes bemutatásra. Így olvashatunk az ENSZ világkonferenciáiról, egyezményeiről és az Emberi Jogok Európai Bíróságának gyakorlatáról is. (B. Á.)

- Természeti és ipari katasztrófák: Jogi aspektusok a 2010-es ajkai vörösiszap-katasztrófa fényében 
Mezei Péter (szerk.)

Szegedi Tudományegyetem Állam- és Jogtudományi Kar, Szeged, 2012

Konferenciakötet. Terjedelem: 160. Bibliográfia a fejezetek végén.

ISBN 9789633061343

- A szerzők PhD-hallgatók. Az Ajkai Timföldgyár egyik tárolójának 2010 októberi gátszakadása eredményeként bekövetkezett vörösiszap-katasztrófa jogi kérdéseinek a vizsgálatára a Szegedi Tudományegyetem Állam- és Jogtudományi Doktori Iskola doktoranduszai konferenciát szerveztek 2011 tavaszán. Az előadásokból készült konferenciakötet öt fejezetben dolgozza fel az esetet, a magánjogi felelősség, az állami szerepvállalás, az egészséghez való jog, a szabadalmi jogi kérdések, valamint a nemzetközi jog és politológia szemszögéből. A kötetben tizenkét magyar nyelvű és egy angol nyelvű tanulmány található. (B. Á.)

- ...Cselekedj lokálisan! Társadalmi részvétel környezeti ügyekben

Pánovics Attila-Glied Viktor (szerk.)

Publikon, Pécs, 2012

Konferenciakötet. Terjedelem: 197. Bibliográfia a tanulmányok végén. ISBN 9786155001727

- A szerzők egyetemi oktatók és gyakorlati szakemberek. A kötet a 2011 decemberében a Dél-dunántúli Regionális Könyvtár és Tudásközpontban tartott konferencia utókiadványa. A konferencia témája a participáció, illetve a partnerség formái és lehetőségei, valamint a részvétel jogi háttere környezeti ügyekben. A kötetben tizenegy tanulmány található, amelyekben a jogászi megközelítés mellett számos egyéb szakterület művelői is megosztják a gondolataikat, úgymint biológusok, politológusok, filozófusok és szociológusok. A tanulmányokban a részvételi demokrácia és a döntéshozatalban elvárt partnerség fejlesztésére helyezik a hangsúlyt, és a helyi közösségek aktivitásának fontosságára hívják fel a figyelmet. (B. Á.)

- A hulladéklerakók rekultivációja, utógondozása

SzABó Imre-SzaBó Attila

Miskolci Egyetem, Miskolc, 2012

Kézikönyv. Terjedelem: 342. Bibliográfia a 317-342. oldalakon. ISBN 9789636616274

- A szerzők egyetemi oktatók, müszaki-természettudományi szakemberek. Napjaink egyik legaktuálisabb hulladékgazdálkodási problémáját átfogó jelleggel tárgyalják. Kézikönyvük a megértést elősegítő fogalomtárral kezdődik, majd külön fejezetekben tér ki a hulladéklerakók rekultivációjának a jogszabályi hátterére, valamint az alkalmazandó hatósági eljárási és engedélyezési rendre. Ez utóbbi keretében a Ket. előírásait, valamint az egyes eljárási fajtákat és az eljárás lefolytatásának menetét ismerteti. Ezt követően a rekultivációs terv követelményeivel, az alapul szolgáló előzetes vizsgálatokkal, valamint a hulladéklerakó lezárásával, rekultivációjával, monitorozásával stb. foglalkozik. A bőséges irodalomjegyzékkel záruló könyvet táblázatok, ábrák és képek színesítik. (Gy. A. Cs.) 
- Természetvédelmi jogi és igazgatási ismeretek

TEMEsı Géza

Dialóg Campus Kiadó, Budapest-Pécs, 2012

Tankönyv. Terjedelem: 118. Bibliográfia: 109. ISBN 9789639950788

- A szerző egyetemi oktató, erdészeti szakember. A kötet hűen követi a törvényi szabályozás rendszerét, azonban didaktikai szempontokat is figyelembe vesz. Foglalkozik a természetvédelem hazai anyagi jogi szabályozásával, állami szervezetrendszerével, eljárásjogi elöírásaival, a természeti területek és értékek őrzésével, megóvásával és fenntartásával, egyes speciális területekkel, így az erdő-, hal- és vadgazdálkodással és -védelemmel, valamint a társadalom részvételével a természet védelmében. A kötetben eligazodást és szemléltetést elősegítő táblázatokkal, ábrákkal, képekkel találkozhatunk. Három függelék zárja a könyvet, köztük a fokozottan védett növény- és állatfajok köréből válogatott lista, azok pénzben kifejezett értékével. (Gy. A. Cs.)

\section{MUNKAJOG}

- Egységes szerkezetbe foglalt munka törvénykönyve magyarázatokkal a munkaadók számára a 2012. évi l. törvény alapján

Bálint Adrienn-Lóródi László (szerk.)

Munkaadók és Gyáriparosok Országos Szövetsége, Budapest, 2012

Jogszabálygyűjtemény. Terjedelem: 207. Bibliográfia nincs. ISBN 9789638916310

- A szerzők gyakorló munkaügyi szakemberek és érdekvédők. A könyv célja a 2012. évi munka törvénykönyve (Mt.) által bevezetett változásoknak a gyakorlati aspektusból való bemutatása, amivel elsősorban a munkáltatók számára kívánnak egyfajta segédletet biztosítani a szerzők. A munkajogi rendelkezések legfontosabb változásainak az összefoglalását követően A munka törvénykönyve egyes szabályait mutatják be, a törvény szerkezetét követve. Az egyes rendelkezéseket követő magyarázatokban az 1992. évi Mt. előírásaival való összehasonlításra is sor kerül. A szabályok jobb megértését táblázatok és a vonatkozó uniós szabályok ismertetése segíti. (B. K.)

- Kommentár a munka törvénykönyvéhez: kommentár a munka törvénykönyvéröl szóló 2012. évi I. törvényhez

BANKó Zoltán-Berke Gyula-KAJTÁR Edit-Kıss György-Kovács Erika

CompLex Kiadó, Budapest, 2012

Kommentár. Terjedelem: 701. Bibliográfia nincs. ISBN 9789632247786

- A kötet szerzői egyetemi oktatók és gyakorlati jogászok. A kiadvány a 2012. július 1-jén hatályba lépett új munka törvénykönyve szakaszainak magyarázata útján kívánja az e jogterületen tevékenykedő szakembereket orientálni. A rendelkezésekhez fúzött kommentárt kiegészíti a bírósági határozatok, munkaügyi kollégiumi 
állásfoglalások révén a hazai bírói gyakorlat bemutatása is. A szerzők ugyanakkor nemcsak a magyar munkajogi szabályozást dolgozták fel, hanem helyet kapott a kapcsolódó európai uniós jogszabályok, illetve ILO-egyezmények ismertetése is. (B. M.)

- A pedagógusokra vonatkozó munkajogi szabályozás I.: 2012. június 30. napjáig Bíró Endre (szerk.)

Jogismereti Alapítvány, Budapest, 2012

Jogszabálygyűjtemény. Terjedelem: 195. Bibliográfia nincs.

ISBN 9789638896537

- A szerző egyetemi oktató és gyakorlati szakember. A kiadvány a 2012. június 30. napjáig hatályos, pedagógusokra irányadó munkajogi szabályozást mutatja be A munka törvénykönyve, a közalkalmazottak jogállásáról szóló törvény, a közoktatásról, illetve a pedagógus-továbbképzésről, a pedagógus-szakvizsgáról, valamint a továbbképzésben részt vevők juttatásairól és kedvezményeiről szóló törvény és az ezekhez kapcsolódó kormányrendeletek alapján. A jogszabályok közötti tájékozódást összevont betürendes címmutató segíti. (B. M.)

- A közalkalmazottak jogállásáról szóló törvény és magyarázata

CsÉFFÁn József

Szegedi Rendezvényszervező Kft., Szeged, 2012

Kommentár. Terjedelem: 944. Bibliográfia nincs. ISBN 9789638701992

- A szerző munkaügyi bíró, egyetemi oktató. Könyve a közalkalmazottakra vonatkozó jogszabályok tekintetében kíván egyértelmủ eligazítást adni, feltárva az új munka törvénykönyve és a közalkalmazottak jogállásáról szóló törvény rendelkezéseinek lényegét. Ehhez felhasználja a gyakorlat iránymutató eseti döntéseit, továbbá munkaügyi kollégiumi állásfoglalásokat és jogegységi határozatokat. A kiadványban való tájékozódást részletes tárgymutató és tartalomjegyzék segíti. (B. M.)

- A munka törvénykönyve és magyarázata

CsÉFFÁn József

Szegedi Rendezvényszervező Kft., Szeged, 2012

Kommentár. Terjedelem: 795. Bibliográfia nincs. ISBN 9789638827289

- A szerző munkaügyi bíró, egyetemi oktató. A könyv a gazdasági munkaviszonyra vonatkozó szabályozás részletes magyarázatát adja, bemutatva a jogszabályi rendelkezésekhez kapcsolódó bírói gyakorlatot, a Kúria Munkaügyi Kollégiumának állásfoglalásait, valamint jogegységi határozatait. A szerző a kötet első részében kitér a régi Mt. 2012. december 31-ig alkalmazandó szabályaira, ezt követi az új Mt. szakaszról szakaszra történő ismertetése. Mindezek mellett a leggyakrabban alkalmazott okiratok szerkesztéséhez iratmintatár nyújt segítséget, valamint a könyvben való tájékozódást részletes tárgymutató és tartalomjegyzék segíti. (B. M.) 
- Segédlet a közalkalmazottak jogállásáról szóló törvényhez CsÉFFÁn József

Szegedi Rendezvényszervező Kft., Szeged, 2012

Kézikönyv. Terjedelem: 209. ISBN 9786155112027

- A szerző közigazgatási és munkaügyi regionális kollégiumvezető bíró. A segédlet három részből áll: az első részben található A munka törvénykönyve (1992. évi XXII. törvény), valamint a közalkalmazottak jogállásáról szóló 1992. évi XXXIII. törvény (Kjt.) 2012. december 31-ig alkalmazandó szövege. A második részben található a munka törvénykönyvéröl szóló 2012. évi I. törvény és a Kjt. 2012. július 1-jétől hatályos szövege. A harmadik rész a részletes tartalomjegyzék. (K. B.)

- Segédlet a munka törvénykönyvéhez

CsÉFFÁn József

Szegedi Rendezvényszervező Kft., Szeged, 2012

Kézikönyv. Terjedelem: 139. Bibliográfia nincs. ISBN 9786155112041

- A szerző közigazgatási és munkaügyi regionális kollégiumvezető bíró. A segédlet három részből áll: az első részben található A munka törvénykönyve (1992. évi XXII. törvény) 2012. december 31-ig alkalmazandó szövege. A második részben található a munka törvénykönyvéröl szóló 2012. évi I. törvény 2012. július 1-jétöl hatályos szövege. A harmadik rész a részletes tartalomjegyzék. (K. B.)

- A munka törvénykönyve, 1992-2012

Domány Katalin (szerk.)

CompLex Kiadó, Budapest, 2012

(Sorozat: A Munkaügyi Jogszabályok Változásai 1., ISSN 2063-7632)

Jogszabálytükör. Terjedelem: 474. Bibliográfia nincs. ISBN 9789632950846

- A szerkesztő gyakorló jogász. Az új munka törvénykönyve 2012. július 1-jei hatálybalépésével a munkajogi szabályok jelentősen megváltoztak. A könyv tükrös formában hasonlítja össze az 1992. évi és a 2012. évi Mt. szabályait, ily módon emelve ki az újdonságokat a munkajogászokon és HR-szakembereken kívül azok számára is, akik megismerni és alkalmazni kívánják a munkajogi rendelkezéseket. $E$ megismerésben kíván segítséget nyújtani a szerkesztő arra az átmeneti bizonytalan időszakra, amíg kialakul az új joggyakorlat. (B. K.)

- Munkajog

DudÁs Katalin-GyulavÁRI Tamás-HoRVÁTH István-Hös Nikolett-KÁRTYÁs GáborKulısity Mária-Kun Attila-Petrovics Zoltán

(Sorozat: ELTE Jogi Kari Tankönyvek 7. ISSN 2060-6494)

ELTE Eötvös Kiadó Kft., Budapest, 2012

Tankönyv. Terjedelem: 589. Bibliográfia fejezetenként és a lábjegyzetekben. ISBN 9789633121054

- A szerzők munkajogász szakemberek, egyetemi oktatók, ügyvédek és bírák. Könyvük egyetemi hallgatók és a munkajoggal foglalkozó gyakorlati szakemberek számára készült. A tankönyv a 2012. évi új munka törvénykönyve (új Mt.) rendelkezéseit, valamint ehhez kapcsolódóan elvi és gyakorlati problémákat ele- 
mez, amelynek során a bírói gyakorlat bemutatása is hangsúlyos szerepet kap, egyúttal a szerzők röviden utalnak a régi és az új szabályok közötti koncepcionális különbségekre. A tankönyv felépítése alapvetően követi az új Mt. szerkezetét, de azon kívüli, ám még a munkajog szerves részét képező témaköröket is magába foglal. A szabályok jobb érthetősége végett számos lábjegyzet, ábra és táblázat található a könyvben, ami hat részre, azokon belül pedig fejezetekre tagolódik. Az egyes fejezetek végén irodalomjegyzék található. (B. K.)

- A régi és az új munka törvénykönyve összehasonlítása kiegészítve a továbbélö bírói gyakorlattal

DudÁs Katalin-HORVÁTH István

Novissima Kiadó, Budapest, 2012

Kézikönyv. Terjedelem: 297. Bibliográfia nincs. ISBN 9786155175435

- A szerzők egyetemi oktatók. Céljuk a könyv összeállításakor az volt, hogy segítsék az átállást a régi munkajogi kódexről az újra. A kiadvány „tükrös” szerkezetben, párhuzamosan, paragrafusról paragrafusra mutatja be az új és a korábbi munkajogi kódex rendelkezéseit, kiemelve a szabályozásban bekövetkezett fontosabb változásokat, továbbá az érintett szakaszokat követően szerepeltetve az átmeneti szabályokat is. (K. B.)

\section{- Munkajog I.}

Ember Alex-Hajdú József-Hegedüs Bulcsú-Homıcskó Árpád Olivér-KáRpÁtı JuditKun Attila-MAREncsák Zsolt-Suba Ildikó

2., átdolgozott kiadás (Sorozat: Bethlen-sorozat, ISSN 2062-2546)

Patrocinium, Budapest, 2012

Egyetemi jegyzet. Terjedelem: 286. Bibliográfia: 276-281. és a lábjegyzetekben. ISBN 9786155107894

- A szerzők egyetemi oktatók és gyakorló jogászok. Könyvük elsősorban a joghallgatók számára készült tankönyv, amely a munkajogi ismeretek elsajátítását könynyíti meg. A könyv a tételes joganyag magyarázata mellett dogmatikai, rendszertani ismereteket és gyakorlati szempontokat is tartalmaz. 2011-es kiadásának átdolgozását az időközben hatályba lépő 2012. évi új munka törvénykönyve által bevezetett változások tették szükségessé. Az individuális munkajog megértését táblázatok és az életből vett példák teszik könnyebbé, amelyet a szerzők kiegészítenek a vonatkozó bírói gyakorlattal. A hazai szabályozás elemzéséhez kapcsolódóan a könyv röviden foglalkozik a munkajog nemzetközi és uniós vonatkozásaival is. (B. K.)

- Munkajogi és vállalkozási ismeretek

Fleischmannn Anna-Stelcz István-Szerényı Attila

Szega Books, Pécs, 2012

Tankönyv. Terjedelem: 232. Bibliográfia: 232. ISBN 9789639702516

- A szerzők gyakorlati szakemberek, könyvük összeállításánál a Magyar Kereskedelmi és Iparkamara által a szakképzésekre kidolgozott programok és ajánlások szóbeli vizsgakérdéseit vették figyelembe. A könyv emellett igazodik a legújabb 
jogszabályi változásokhoz (2012. évi I. tv., új Mt.). A jogi alapfogalmak rövid ismertetése után az új Mt. alapján kerülnek kiemelésre a legfontosabb ismeretek a munkavállalók, valamint a munkáltatók számára. A könyv foglalkozik a munkaerő-kölcsönzés szabályaival, valamint a munkaügyi kapcsolatokkal. A jogi ismertetésen túl a vállalkozásokkal kapcsolatos fejezeteket tartalmaz, bemutatva azok környezetét, legfontosabb típusait, alapítását, gazdálkodását. Alapvető számviteli, gazdasági, adózási és társadalombiztosítási ismereteket részletez. Esettanulmányok és önellenőrző kérdések segítik a tanulást. (K. B.)

- A Munka Törvénykönyve 2012

GYULAVÁRI Tamás-Hös Nikolett-KÁRTYÁs Gábor-TAKÁcs Gábor Kompkonzult, Budapest, 2012

Kézikönyv. Terjedelem: 403. Bibliográfia: 401-403. ISBN 9789639427860

- A szerzők egyetemi oktatók és a munkajog területén tevékenykedő gyakorló jogászok. A könyv célja, hogy a munka törvénykönyvéről szóló 1992. évi XXII. törvény (Mt.) 1992-ben történt hatálybalépését követően bekövetkező törvényi változásokat bemutassa. A szerzők az uniós jogharmonizációs követelményeket, valamint a közösségi és a hazai joggyakorlat azon feltételeit is elemzik, amelyek e változásokat szükségszerüen indokolták. A törvény rendelkezései állásfoglalásokkal és magyarázatokkal egységes szerkezetben találhatók, amelyek a fontosabb jogeseteket, a munkaügyi bíróságok érdekesebb döntéseit, gyakorlatát is bemutatják. A szerzők figyelemmel voltak a szakmai folyóiratokban megjelent publikációkra is. (B. K.)

- Jogi alapismeretek: Munkajog és társadalombiztosítási jog igazságügyi igazgatási alapszakos hallgatók számára Gecse Istvánné-Tománé SzABó Rita-Kenderes György Novotni Kiadó, Miskolc, 2012 Egyetemi tansegédlet. Terjedelem: 272. Bibliográfia nincs. ISBN 9639360260

- A szerzők egyetemi oktatók, illetve gyakorlati szakemberek. Könyvük az igazságügyi igazgatási alapszakos hallgatók számára készült tansegédlet, amelynek célja a gazdasági munkaviszony, illetve a társadalombiztosítási rendszer szabályozásának bemutatása. A kiadvány tartalmazza az új Munka törvénykönyve legfontosabb rendelkezéseit, például a munkaviszony létrejöttére és megszűnésére, a munka díjazására vagy a munka- és pihenőidőre vonatkozóan. Ezen túlmenően foglalkozik a társadalombiztosítás alapjaival, az abból finanszírozott ellátásokkal és kitér a foglalkoztatáspolitika intézményrendszerére is. (B. M.)

- A magyar munkajog I-IV.: kommentár a gyakorlat számára

Hajdu Edit-Mészárosné Szabó Zsuzsanna-Radnay József-Tallián Blanka-Tálné MOLNÁR Erika

Negyedik kiadás. HVG-ORAC, Budapest, 2012

Kommentár. Terjedelem: cserélhető lapok. Bibliográfia nincs. ISBN 9789638213310 
- A szerzők bírák, egyetemi oktatók. A négykötetes kapcsos kommentárban a 2012. évi új munka törvénykönyve, valamint a közszolgálati tisztviselőkről szóló törvény magyarázata található, amely a munkajoggal hivatásszerüen foglalkozó jogászok, HR- és gazdasági vezetők számára készült. A kommentár elsősorban a bírói gyakorlatra koncentrál, s a negyedik kiadásban már csak a korábbi ítélkezési gyakorlat azon része szerepel, amely az új szabályozási közegben is irányadó, s a szerzők bemutatják, mely részei nem helytállók többé. A könyvben az uniós munkajogi szabályok ismertetésére is sor kerül. A kommentár kapcsos formájának köszönhetöen mindig naprakész. (B. K.)

\section{- Munkajogi példatár}

Hajdú József-Kun Attila (szerk.)

Patrocinium, Budapest, 2012

(Sorozat: Wesselényi-sorozat)

Tansegédlet. Terjedelem: 235. Bibliográfia nincs. ISBN 9786155107429

- A szerzők és szerkesztők egyetemi oktatók. A példatár kiegészíti a szerkesztők Munkajog I-Il. címü egyetemi jegyzetét. A szerzők célja, hogy a munkajogi szemináriumokat gyakorlatorientálttá alakítsák, s ily módon felkészítsék a hallgatókat a gyakorlati élet kihívásaira. A példatár már a 2012. évi I. törvény (Mt.) szabályainak figyelembevételével, de még az 1992. évi Mt. alapján kialakult bírói gyakorlat alapján készült. Négy nagy témakörben tartalmaz fiktív, sematizált jogeseteket: az Mt. általános rendelkezései, a munkaviszony, a munkaügyi kapcsolatok, valamint a munkaügyi vita. Minden tényállás végén orientáló kérdések találhatók. ( $B$. K.)

- Munkajogi navigátor: az új Munka törvénykönyve a gyakorlatban

HoRVÁtH István-SzABó Tibor

(Sorozat: Önadózó Kézikönyvek, ISSN 1789-4751)

Adónet.hu Zrt., Budapest, 2012

Kommentár. Terjedelem: 531. Bibliográfia nincs. ISBN 9789638830999

- A könyv egy egyetemi oktató és egy gyakorlati szakember közös munkája, melynek célja azon kérdés megválaszolása, hogy mennyiben lesz más munkavállalókat foglalkoztatni, avagy egy munkahelyen dolgozni 2012. július 1-je, azaz a munka törvénykönyvéről szóló 2012. évi I. törvény hatálybalépése után. A kérdés megválaszolását az új Mt. szakaszaihoz füzött részletes magyarázat, ennek részeként a kapcsolódó bírósági határozatokon keresztül a joggyakorlat ismertetése, továbbá az átmeneti rendelkezésekről és törvénymódosításokról szóló 2012. évi LXXXVI. törvény bemutatása és iratmintatár szolgálja. (B. M.)

- Az új Munka Törvénykönyve - Értelmezés és alkalmazás a gyakorlatban HORVÁTH István Vezinfó, Budapest, 2012

Szakkönyv. Terjedelem: 296. Bibliográfia nincs. ISBN 9786155085031

- A szerző egyetemi oktató, ügyvéd; a 2012. július 1-jén hatályba lépett új munka törvénykönyve (továbbiakban: Mt.) rendelkezéseit veszi górcső alá. A könyv kéziratának lezárásakor bizonytalan volt az Mt. egyes rendelkezéseinek hatálybalé- 
pése, ezért a szerző eltérő színekkel jelölte meg a hatálybalépéshez kapcsolódó átmeneti rendelkezéseket, a módosított törvényszöveget és azokat a szövegrészeket, amelyek a módosító törvény következtében nem léptek hatályba. A gyakorlat és az elmélet szintéziseként, a törvény felépítését követve, közérthetően veszi sorra az általános rendelkezéseket, a munkaviszony alanyai és létesítése, a munkaszerződés teljesítése és módosítása, a munkaügyi kapcsolatok, a munkaügyi vita szabályait és a záró rendelkezéseket. (D. D.)

- Munkaügyi ellenörzés a gyakorlatban: törvényi elöírások, jogok, kötelezettségek, felkészülési segédletek munkáltatóknak Horváth Viktória-Torgyik Varga Edina (szerk.)

2., átdolgozott kiadás

Menedzser Praxis, Budapest, 2012.

Szakkönyv. Terjedelem: cserélhető lapok. Bibliográfia nincs. ISBN 9632298551

- A szerkesztők az államigazgatásban dolgozó szakemberek. Az időközben bekövetkezett jogszabályi változások tették indokolttá egy szerkezetileg és tartalmilag is megújult könyv kiadását. A kötet anyaga segítséget nyújt a munkaerőpiac szereplőinek a munkaügyi ellenőrzés rendszerének könnyebb megértéséhez. Önálló fejezetben kapott helyet a munkaügyi hatósági ellenőrzést érintő nemzetközi és hazai jogszabályi környezet bemutatása, a hatóság szervezeti felépítése. Hangsúlyosan jelenik meg a munkaügyi ellenőrzés speciális szabályainak gyakorlati ismertetése, az ellenőrzési tárgykörök és intézkedési lehetőségek bemutatása, illetve a hatóság nyilvántartási és adatszolgáltatási tevékenysége. Az egyes ellenőrzési hatáskörök és a felügyelők intézkedési lehetőségei a gyakorlat tükrében kerülnek bemutatásra, törekedve a kapcsolódó szabályok ismertetésére is. (K. B.)

\section{- Szakmai kommunikáció és módszertan a munkavédelemben}

KaPÁs Zsolt

OMKT Kft., Budapest, 2012

Szakkönyv. Terjedelem: 104. Bibliográfia: 100-104. ISBN 9789638905864

- A szerző okleveles gépészmérnök, munkavédelmi szakmérnök. A könyv a munkavédelmet, a munkahelyi egészséget és biztonságot, a munkahelyi egészségfejlesztést mutatja be több szemszögből. A munkavédelmi szabályozás rendszeréből kiindulva elemzi a munkavédelmi kommunikációt, szól a tárgyalástechnikai alapokról, átfogó megelőzési stratégiáról. Bemutatja a MOBIUS modellt, valamint a sikertelen kommunikáció hatásait. (K. B.)

- Az új munka törvénykönyve munkáltatóknak

KÁRTYÁs Gábor-TAKÁcs Gábor

CompLex Kiadó, Budapest, 2012

(Sorozat: Munkajogi Kiskönyvtár 2. ISSN 2063 6393)

Szakkönyv. Terjedelem: 265. Bibliográfia nincs. ISBN 9789632952185

- A szerzők egyetemi oktatók, illetve gyakorló jogászok. A 2012. évi új munka törvénykönyve (új Mt.) megismerésében kívánnak segítséget nyújtani a kifejezetten munkáltatók számára készült könyvben. A részletszabályok ismertetése helyett a 
munkajogi szabályozás lényeges változásaira térnek ki, kifejezetten meg is jelölve, hogy egy-egy szabály vagy fogalom korábban milyen tartalommal bírt, s hogy azon milyen módon változtatott az új Mt. A szerzők a jogszabály ismertetését és értelmezését elsősorban a gyakorlat felől közelítve végzik, s a jobb megértés érdekében táblázatok is elhelyezésre kerültek a kötetben. (B. K.)

- Új munkajogi szabályok az egészségügyben: ügyelet, készenlét, munkaidő-beosztás Köszegfalvı Edit

CompLex Kiadó, Budapest, 2012

(Sorozat: Egészségügyi Kiskönyvtár 3. ISSN 2063-2282)

Kézikönyv. Terjedelem: 230. Bibliográfia nincs. ISBN 9789632950129

- A szerző oktató és gyakorló biztosítási-munkajogi szakjogász. 2012. július 1-jével A munka törvénykönyve hatálybalépése mellett az egészségügyi dolgozókra vonatkozó speciális ágazati szabályok is jelentős mértékben módosultak. A munkaidőre, pihenőidőre és az illetménytáblára vonatkozóan az általános munkajogi szabályok csak az ágazati szabályokkal együtt alkalmazhatóak. A könyv alapvető célja, hogy az új munka törvénykönyve hatálybalépésével egyidejüleg az olvasók megismerjék ezeket a speciális ágazati szabályokat. (K. B.)

- Az új Mt. hatálybalépése, az átmeneti rendelkezések - Az Mth. magyarázata

LőRINCz György

HVG-ORAC Budapest, 2012

Kommentár. Terjedelem: 224. Bibliográfia nincs. ISBN 9789632581590

- A szerző ügyvéd, gyakorló jogász. A könyv a munka törvénykönyvéről szóló 2012. évi I. törvény (Mt.) hatálybalépésével összefüggő átmeneti rendelkezésekről és törvénymódosításokról szóló törvény (Mth.) szabályainak magyarázatát tartalmazza. A kommentár az új rendelkezésekre történő áttérést segíti, elsősorban a gyakorlat számára. Két nagy részből áll: az első az Mth. ún. átmeneti rendelkezéseit tartalmazza, amelyben a szerző a törvény szövegét követve, annak egyes paragrafusaihoz füz magyarázatot, s ennek megfelelően a kommentár felépítése a törvény szerkezetét követi; a második rész az új Mt. hatálybalépése következtében indokolt törvénymódosítások kivonatos változatát tartalmazza, ugyanis kizárólag a munkaviszonnyal kapcsolatos módosítások kerülnek ismertetésre. (B. K.)

- A munka- és közszolgálati jog intézményrendszerének kritikai és összehasonlító elemzése

Prugberger Tamás-Kenderes György-MéLyPATAKı Gábor

Novotni Alapítvány, Miskolc, 2012

Egyetemi tankönyv. Terjedelem: 448. Bibliográfia a fejezetek végén.

ISBN 9789639360686

- A szerzők egyetemi oktatók, könyvüket kifejezetten egyetemi hallgatóknak szánták. Előzményének tekinthető a 2009-ben megjelent „A munka- és a közszolgálati jog intézményrendszerének kritikai és összehasonlítójogi elemzése” című kötet, amelynek kibővített tartalommal és új címmel történő kiadását az időközben bekövetkezett változások tették szükségessé. A munkajog jellege és történeti ala- 
kulása, az individuális munkajog és közszolgálati jog alapintézményei, a kollektív munkajog, valamint a munkaügyi viták és jogviták rendszere kerül részletes elemzésre és bemutatásra. A szerzők összevetették a hazai szabályokat mind az EU tagállamainak jogával, mind az uniós joggal. Az egyes fejezetek végén fellelhető az adott témához tartozó források és irodalom jegyzéke. (B. K.)

- Munka törvénykönyve 2012

OMI Kft., Szeged, 2012

Jogszabálygyüjtemény. Terjedelem: 258. Bibliográfia nincs.

ISBN 9789630843805

- A kiadvány a munka törvénykönyvéröl szóló 2012. évi I. törvény és az ennek hatálybalépésével összefüggő átmeneti rendelkezésekről és törvénymódosításokról szóló 2012. évi LXXXVI. törvény rendelkezéseit tartalmazza, melyek között az eligazodást részletes tartalomjegyzék segíti. A/6-os, zsebkönyvméretben jelent meg. (B. M.)

- Az új Munka Törvénykönyvének magyarázata

PÁl Lajos-LöRIncz György-Kozma Anna-PetHö Róbert

HVG-ORAC, Budapest, 2012

Kommentár. Terjedelem: 490. Bibliográfia a lábjegyzetekben.

ISBN 9789632581491

- A szerzők ügyvédek, gyakorló jogászok. A könyv kifejezetten a 2012. évi I. törvény, az új munka törvénykönyve (új Mt.) magyarázatát tartalmazza, felépítése a törvény szerkezetét követi. Az egyes paragrafusokat követő részletes magyarázatban a szerzők rávilágítanak az összefüggésekre, egyúttal kiemelik azt is, hogy a korábbi törvényhez képest mi, miért és hogyan változott, s hogy e változások várhatóan milyen hatással lesznek a gyakorlatra. A kommentár jelentős részben támaszkodik a bírói gyakorlatra, alaposan feldolgozva azt: a több száz anonim bírósági határozat, valamint a számtalan $\mathrm{BH}$ és $\mathrm{EBH}$ mellett a Kúria kollégiumi állásfoglalásai és elvi határozatai kerülnek ismertetésre. A kötethez CD-melléklet tartozik, amely hatvanhárom, az új Mt. szerint készült, szerkeszthető munkajogi iratmintát tartalmaz. (B. K.)

- A munka törvénykönyve, 1992-2012

Szűcs Péter (szerk.)

(Sorozat: A Munkaügyi Jogszabályok Változásai 1. ISSN 2063-3432)

CompLex Kiadó, Budapest, 2012

Jogszabálygyűjtemény. Terjedelem: 474. Bibliográfia nincs.

ISBN 9789632950846

- A szerkesztö ügyvéd, tükrös formában hasonlítja össze a munka törvénykönyvéről szóló 1992. évi XXII. törvényt a 2012. évi I. törvénnyel, azaz a régi szabályozást az újjal. Az összehasonlítás alapjaként az új jogszabályt használja, ezzel is segítséget nyújtva az átálás időszakában a joggyakorlat kialakulásáig. A könyv ezen túlmenően bemutatja az új törvény megalkotásának körülményeit, céljait, valamint tartalmazza az ahhoz elfogadott hivatalos indokolást. (B. M.) 


\section{PÉNZÜGYI JOG}

- Pénzügyi alapok: Tapasztalatok és tanulságok pénzügyi válság után Bod Péter Ákos Magyar Szemle Alapítvány, Budapest, 2012

Kézikönyv. Terjedelem: 304. Bibliográfia: 299-300. és a lábjegyzetekben. ISBN 9786155227011

- A szerző egyetemi oktató, a Magyar Nemzeti Bank egykori elnöke. A könyv a legutóbbi pénzügyi válságot követő időszak pénzügyi változásait dolgozza fel. Célja, hogy eligazítást nyújtson a pénzkapcsolatok mai, a társadalmi életet jelentősen meghatározó rendszerében. A könyv a pénzvilág alapfogalmainak tisztázásával indul. Tizenkét fejezeten keresztül bemutatásra kerülnek a pénzügyi piacok, a pénz világának legfontosabb szereplői, intézményei, nemzetközi szervezetei, valamint az állami pénzpolitika. Olyan kérdéseket boncolgat, melyek a pénzügyi válságok vagy épp az euró sikerességének megítéléséhez adnak támaszpontot. A szerző az olvasóra bízza a végső következtetések levonását. A fejezetek sorai között számtalan példa, míg a végén olvasmányok és gondolkodásra serkentő kérdések színesítik a könyvet. (B. P.)

- Pénzügyi jog II.

Simon István (szerk.)

Osiris Kiadó, Budapest, 2012

Tankönyv. Terjedelem: 577 . Bibliográfia az egyes fejezetek végén. ISBN 9789632762289

- A szerzők elsősorban egyetemi oktatók, soraik között tudhatunk továbbá gyakorlati szakembereket is. A kiadvány a korábban azonos címen megjelent munka negyedik, átdolgozott kiadása. Tematikáját és struktúráját tekintve megegyezik az öt évvel ezelőtt kiadottal, ám az azóta bekövetkezett változásokat sorra veszi, ami miatt a korábbi mü egyes fejezetei részben, míg más egységei teljes egészében - például az általános forgalmi adóról vagy a nemzetközi adójogról szólók - újraírásra kerültek. Az aktualitások jegyében helyet kaptak a kötetben a 2007 óta bevezetett fizetési kötelezettségek (pl. baleseti adó, népegészségügyi termékadó, rehabilitációs hozzájárulás) is. (V. J.)

- Az államháztartási számvitel alapjai és a közpénzügyi információs rendszer SimON József

CompLex Kiadó Jogi és Üzleti Tartalomszolgáltató Kft., Budapest, 2012 Tankönyv. Terjedelem: 256. Bibliográfia: 243-251. ISBN 9789632952215

- A szerző főiskolai docens. A kiadvány, mely egy négykötetes tankönyvsorozat harmadik részeként született meg, hiánypótló célokat szolgálva igyekszik eligazítani az olvasót az államháztartás pénzügyi információs rendszerével kapcsolatos elméleti és gyakorlati ismeretek között. A könyv első két szerkezeti egysége a téma alapozásának tekinthető, mely a pénzügyi információs rendszer jelentőségébe és a számvitel alapjaiba kalauzolja el az olvasót. Ezek után kerül sor az államháztartás pénzügyi információs rendszerének, valamint történeti fejlődésének 
bemutatására, majd nemzetközi kontextusba helyezésére, s végül a kapcsolódó, hatályos magyar jogszabályi rendelkezések felvázolására. Ahogy azt a sorozat többi kötetétől megszokhattuk, keretes írások, grafikonok, táblázatok és ábrák teszik még szemléletesebbé a szerző mondanivalóját, valamint az egyes fejezetek végén a bemutatott téma kulcsfogalmainak kigyűjtése és ismétlő, illetve megvitatásra ajánlott kérdések segítik az olvasót az ismeretanyag elmélyítésében. (V. J.)

- Rendhagyó bevezetés közpénzügyek tanulmányozásába

SIVÁK József-VIGVÁRI András

CompLex Kiadó Jogi és Üzleti Tartalomszolgáltató Kft., Budapest, 2012

Tankönyv. Terjedelem: 261. Bibliográfia: 255-258. ISBN 9789632950655

- A szerzők egyetemi oktatók, illetve kutatók. A kiadvány egy több kötetre tervezett tankönyv-kézikönyv sorozat első darabja, melyben az alkotók a közpénzügyekkel kapcsolatos elméleti alapok, fogalmak, illetve összefüggések bemutatására törekszenek, amelyek képessé teszik az olvasót a közpolitikai, közpénzügyi kérdések közötti eligazodásra, valamint a később megjelenő kiadványok tartalmának értelmezésére. A kötet valamennyi fejezete elöbbi célokra figyelemmel lényegre törően, az összefüggésekre fókuszálva ismerteti az olvasóval a közpénzügyek, közszükségletek, kollektív javak fogalmait; mutatja be az állami szerepeket, államháztartási funkciókat, állami beavatkozások típusait. Külön fejezet szól a közösségi döntésekröl, és azok költségvetési joggal való összefüggéseiröl, ahogy a költségvetésről is. Az utolsó két szerkezeti egység, mely a többszintű kormányzat pénzügyi kérdéseit, illetve az állam gazdasági folyamatokra gyakorolt hatását ismerteti, az előző fejezetek során elsajátított ismereteket felhasználva vezeti át az olvasót a második - „A magyar államháztartás és az Európai Unió közpénzügyei” címet viselő - kötetbe. (V. J.)

- Bevezetés az európai uniós támogatások rendszerébe

SzaBó Zsolt

Patrocinium Kft., Budapest, 2012

Monográfia. Terjedelem: 221. Bibliográfiát nem tartalmaz. ISBN 9786155107757

- A szerző egyetemi adjunktus. A szóban forgó kiadvány az Európai Unió 20072013 közötti költségvetési időszakának Strukturális Alapokból származó támogatásainak felhasználására vonatkozóan igyekszik eligazítani az olvasót az uniós és hazai jogszabályok rendelkezései között. A mű első két fejezete alapozási funkciót betöltve, az uniós kohéziós politika általános kérdéseibe, alapelveibe, illetve célkitüzéseibe kalauzol el. Ezek után a szerző a stratégiai programozás folyamatát, a speciális támogatási formákat, az EU-s pénzalapok hozzájárulásainak szabályait, a fejlesztéspolitika intézményrendszerét, a pályázati rendszert, majd az ellenőrzési, pénzügyi lebonyolítási struktúrát, végül pedig az esetlegesen előforduló pénzügyi szankciókat mutatja be. (V. J.) 
- Adózás

SzTANÓ Imréné

Saldo Pénzügyi Tanácsadó és Informatikai Zrt., Budapest, 2012

Tankönyv. Terjedelem: 448. Bibliográfia: 447-448. ISBN 9789636384203

- A 2012-ben napvilágot látott kötet a szerző korábban azonos címen megjelent munkájának harmadik, átdolgozott és hatályosított kiadása, amelyben a vagyonadó már nem, de a 2012-re egyre jelentősebbé váló különadók bemutatására sor kerül. A kiadvány az „Adótani alapok” című könyvre épít, ezért az általános adózási alapismeretek tárgyalásától tartózkodik, az adózás gyakorlatára fókuszál. A kiadvány anyagi jog orientált, bemutatja a legfontosabb hazai adókra - így az általános forgalmi adóra, jövedéki adóra, társasági adóra, személyi jövedelemadóra, egyszerűsített vállalkozói adóra, egyszerűsített közteherviselési hozzájárulásra, helyi adókra, gépjárműadóra, különadókra - vonatkozó szabályokat, valamint a kötet végén az adóeljárásra vonatkozó szabályozás sarokköveinek felvázolására is sor kerül. (V. J.)

- Felsőoktatás-finanszírozás - Nemzetközi tendenciák és a hazai helyzet Temesi József (szerk.)

Aula Kiadó Kft., Budapest, 2012

Tanulmánykötet. Terjedelem: 338. Bibliográfia az egyes fejezetek végén. ISBN 9789633390320

- A szerzők egyetemi oktatók. A jelenlegi munka a 2004-ben „Finanszírozás és gazdálkodás a felsőoktatásban” címmel, ugyancsak Temesi József szerkesztésében napvilágot látott kiadvány mintegy folytatásának is tekinthető, azonban azon túllép, azzal, hogy bemutatja az azóta bekövetkező változásokat, illetve hogy jelentősen bővíti a téma nemzetközi vonatkozásait. A kötet két részre tagolódik. Az első egységben a nemzetközi tendenciákra fókuszáló értekezések kaptak helyet, melyek kitérnek a finanszírozást érintő reformokra, a Kelet-Közép-Európában, valamint a nyugati országokban megfigyelhető trendekre, illetve az európai szintű diákhitelrendszerre. A második részben a felsőoktatás hazai helyzetét, történetét leíró, illetve problémafelvető, javaslatokat megfogalmazó tanulmányok találhatók. (V. J.)

\section{POLGÁRI JOG ÉS POLGÁRI ELJÁRÁSI JOG}

- A kereskedelmi ügyletek joga

Fézer Tamás-Károlyi Géza (szerk.)

Kapitális, Debrecen, 2012

Tankönyv. Terjedelem: 416. Bibliográfia: 415-416. ISBN 9789630849197

- A szerzők a DE ÁJK és a DE KTK egyetemi oktatói. A kötet a kereskedelmi ügyletek komplex bemutatását tủzi céljául: a hatályos joganyag ismertetésén túl a bírói gyakorlatot és a gazdasági szereplők jogfelfogását, joggyakorlatát, a kereskedelmi szokásokat is feldolgozza, rendszerezi. Nem csupán a hagyományos kereskedelmi szerződéseket foglalja magában, hanem kitér az újabb, modernebb 
formákra is, mint amilyen az elektronikus kereskedelem és elektronikus alárás, az atipikus szerződések és a fogyasztóvédelem területe. Mindennek szükségességét a szerzők a gazdasági élet felgyorsult fejlődésével, Magyarország uniós tagságával indokolják. A szerzők szándéka szerint a kötet a jogi oktatásban jelentős segítséget nyújt, de azon túlmenően a szélesebb szakmai közönség is hasznosíthatja. (T. E.)

- A kereskedelmi jog alanyai - Cégek és civil szervezetek joga

Fézer Tamás-Károlyi Géza (szerk.)

Kapitális, Debrecen, 2012

Tankönyv. Terjedelem: 428. Bibliográfia: 427-428. ISBN 9789630835039

- A szerzők a DE ÁJK és a DE KTK egyetemi oktatói. A kötet a gazdasági élet szereplőinek - kiemelten a gazdasági társaságoknak, de emellett az egyéni vállalkozásnak és egyéni cégnek, a mezőgazdasági termelőknek, a speciális társasági formáknak, a civil szektornak és az Európai Unió társasági jog területén folytatott jogalkotási tevékenységének, valamint a versenyjog anyagi jogi szabályainak is - a bemutatására vállalkozik a hatályos joganyag alapján, komplex jelleggel, beépítve a vonatkozó bírósági és versenytanácsi joggyakorlatot is. A társasági jog új, az európai és a globális kihívásoknak is eleget tenni igyekvő szabályozásának rendszerbe foglalt áttekintése egyaránt hasznos lehet a gyakorló jogászok és az egyetemi hallgatók számára. (T. E.)

- Kollektív fogyasztói jogérvényesítés

Hajnal Zsolt (szerk.)

FOME, Debrecen, 2012

Kézikönyv. Terjedelem: 206. Bibliográfia nincs. ISBN 9786155025068

- A szerzők fogyasztóvédelemmel foglalkozó szakemberek: a tudományos élet, a civil szféra és a polgári jogalkalmazás és az ügyészség munkájában vesznek részt. $A$ kötet olyan tudományos igénnyel készült mü, mely a gyakorlati szakemberek munkájához is segítséget kíván nyújtani a fogyasztói közérdekű keresetek terén. A mü elméleti megalapozást követően a megírásakor hatályos joganyag és joggyakorlat kommentárját tartalmazza. A kollektív fogyasztói jogérvényesítés területén hiánypótló, az átalakulásban lévő jogi szabályozás (Fgytv. módosítási folyamata és az új Ptk. kodifikációs folyamata) bemutatását ugyan mellőző, de mégis komplex jellegű könyvet tarthat kezében az olvasó. (T. E.)

- Magyar polgári jog: általános rész

JoBBáGYı Gábor

Szent István Társulat, Budapest, 2012

Jegyzet. Terjedelem: 112. Bibliográfia: 110-112. ISBN 9789633616048

- A szerző egyetemi oktató, jelen műve lényegre törően tartalmazza a polgári jog (magánjog) és a polgári jog tudományának történeti áttekintését a római jogtól kezdődően a nagy kodifikációk korán keresztül napjainkig, valamint bemutatja a polgári jog legfontosabb alapfogalmait, jogági elhelyezését és a magánjog irá- 
nyító eszméit a Ptk. alapelvein keresztül. A kiadvány kitér a polgári jog forrásaira, a polgári jogviszony jellemzőire és a jogi tények rendszerének bemutatására is. Noha a jegyzet írásakor az 1959. évi Ptk. volt hatályban, a polgári jog általános szabályainak időtállósága miatt az alkotás a 2013. évi (új) Ptk. hatálybalépését követően is ugyanolyan haszonnal forgatható. (B. L.)

- Polgári jogi fejlődés az angol és a skót jogban

KeCSKÉs László

HVG-ORAC, Budapest, 2012

Monográfia. Terjedelem: 340. Bibliográfia: 374-388. ISBN 9789632581316

- A szerző egyetemi oktató, műve a 2009-ben megjelent „A polgári jog fejlődése a kontinentális Európa jogrendszereiben" című könyv tematikus folytatásának tekinthető. A kiadvány sajátossága, hogy erős történelmi beágyazottsággal tárgyalja az angol és a skót jogfejlődési mozzanatokat, valamint hogy az egyes fejezetek jellegük és müfajuk alapján is jelentősen eltérnek egymástól. A szerző a common law kialakulását egy dogmatikai bevezetést követően az angol jogtörténet korai szakaszától kezdi, majd bemutatja többek között, hogy miképpen alakult ki a gyakorlatias angol jogászképzés, melyek a precedensek alkalmazásának technikái, továbbá, hogy milyen kapcsolatban van a common law a római joggal és a kontinentális joggal. A könyv a skót joggal külön foglalkozik, kiemelve azokat a sajátosságokat, amelyek az angol jog átvétele után is megnyilvánulnak. (B. L.)

- Választottbírók könyve

KECSKÉs László-LUKÁcs Józsefné

HVG-ORAC, Budapest, 2012

Kézikönyv. Terjedelem: 824. Bibliográfia nincs. ISBN 9789632581507

- A könyv szerzőinek szakmai tevékenysége szorosan összefonódik a választottbíráskodással, így átfogó képet kapunk nemcsak a hazai, de a nemzetközi szabályozásról is. A kötet a választottbíráskodással összefüggő jogszabályok részletes elemzését adja, ehhez kapcsolódóan pedig több mint négyszáz oldalon, közel kétszáz esetet dolgoz fel bírósági és alkotmánybírósági határozatok, valamint a Magyar Kereskedelmi és Iparkamara Mellett Szervezett Állandó Választottbíróság határozatainak elemzésével. (U. K.)

- Magyar polgári eljárásjog

KENGYEL Miklós

Tizenegyedik, átdolgozott kiadás. Osiris Kiadó, Budapest, 2012

(Sorozat: Osiris Tankönyvek, ISSN 1218-9855)

Tankönyv. Terjedelem: 652. Bibliográfia a fejezetek végén.

ISBN 9789632762241

- A szerző egyetemi tanár, kötete a polgári eljárásjog oktatásának egyik alapműve, tizenegyedik, átdolgozott és hatályosított kiadás, mely a 2012-ben bekövetkezett változásoknak megfelelően mutatja be a polgári eljárásjog hatályos szabályait. L. a korábbi kiadás annotációját, Pro Futuro 2012/2, 166. (F. Á.) 
- Nemzetközi magánjog és nemzetközi gazdasági kapcsolatok joga

MÁdL Ferenc-VÉKÁs Lajos

ELTE Eötvös Kiadó, Budapest, 2012

Monográfia. Terjedelem: 555. Bibliográfia a fejezetek végén.

ISBN 9789633121313

- A szerzők a nemzetközi magánjog elismert szakértői, az ELTE egyetemi oktatói. A monográfia a nemzetközi magánjogi viszonyokra vonatkozó szabályozást, valamint a nemzetközi gazdasági kapcsolatok jogát mutatja be. Ezen, új kiadás a terület hazánk uniós tagságával összefüggő változásait is tartalmazza. A kötet a magyar és az európai nemzetközi magánjog sokoldalú kézikönyve, amely a jogi oktatást, a jogtudományt, a jogalkotást és a jogi gyakorlatot egyaránt szolgálja. (K. J. M.)

- Szerződések a szellemi alkotások szolgálatában

PetKó Mihály

Debrecen, 2012

Kézikönyv. Terjedelem: 194. Bibliográfia: 194. ISBN 9789630842181

- A szerző a DE ÁJK egyetemi oktatója. A kötet az Európai Unió normáihoz való igazodás keretében történt magyar újraszabályozás legföbb eredményeit ismerteti a szellemi alkotások területén, az egyes szellemi alkotásokhoz füződő szerződéstípusok bemutatásával. A létrejött joganyag a korábbinál egységesebb, müfajspecifikus rendelkezéseket tartalmaz, és a nemzetközi tendenciákat is nagyobb mértékben követi. A szerző a könyvben található szerződéseket illetően a hagyományostól eltérő csoportosítási szempontot alkalmaz: kötelmi és dologi típusú ügyleteket különböztet meg, melyből előbbiek korlátozottabbak, csupán a felhasználást teszik lehetővé, míg utóbbiak a vagyoni jogok átruházására is lehetőséget adnak. (T. E.)

- Tansegédlet a polgári jogi záróvizsgához „A” tételek

SÁNDOR István

2., átdolgozott kiadás, Patrocinium, Budapest, 2012

(Sorozat: Werbőczy-sorozat, ISSN 2062-2538)

Egyetemi jegyzet. Terjedelem: 380. Bibliográfia az egyes tételek után. ISBN 9786155107559

- A szerző egyetemi oktató és ügyvéd. A jegyzet célja elsősorban az államvizsgára történő felkészítés, amit a tételek sematikus ismertetése, valamint a jogszabályok és az irodalom megjelölése tesz lehetővé. Polgári jogi alapfogalmakkal, társasági joggal, valamint szellemi tulajdonnal kapcsolatos tételeket dolgoz fel. A jogszabályi hátteret még az 1959. évi IV. törvény adja, így ajánlott a hatályos joganyaggal való összevetés. (U. K.)

- Tansegédlet a polgári jogi záróvizsgához „B” tételek

SÁNDOR István

210 2., átdolgozott kiadás, Patrocinium, Budapest, 2012 
(Sorozat: Werbőczy-sorozat, ISSN 2062-2538)

Egyetemi jegyzet. Terjedelem: 154. Bibliográfia az egyes tételek után. ISBN 9786155107566

- A szerző egyetemi oktató és ügyvéd. A jegyzet célja elsősorban az államvizsgára történő felkészítés, amit a tételek sematikus ismertetésével tesz lehetővé. Dologi jogi, öröklési jogi, valamint családi jogi tételeket dolgoz fel, melyekhez megjelöli a vonatkozó jogszabályokat, illetve a kötelező és az ajánlott irodalmat. A jogszabályi hátteret még az 1959. évi IV. törvény adja, így ajánlott a hatályos joganyaggal való összevetés. (U.K.)

- Mediáció - Közvetítői eljárások

Sáriné Simkó Ágnes (szerk.)

HVG-ORAC Kiadó, Budapest, 2012

Tankönyv. Terjedelem: 513. Bibliográfia a kiadvány elején.

ISBN 9789632581835

- A szerzők egyetemi oktatók, illetőleg gyakorló jogászok. A könyv célja, hogy bemutassa a hazánkban már müködő békéltető, közvetítő testületek munkáját, nem hagyva ki a választottbírósági eljárás keretében folytatott közvetítést sem. A kötetben megtalálhatók azok az ügycsoportok, amelyekben a közvetítésnek már hazánkban is többéves múltja van (ezek elsősorban a családjogi konfliktusokhoz, a fogyasztóvédelemhez és az egészségügyhöz, valamint nagyobb vállalatok, cégek közötti szerződéses kapcsolathoz, munkajoghoz kapcsolódnak), és megismerheti az olvasó a közvetítésre vonatkozó hazai jogkörnyezetet, ideértve az Országgyűlés által nemrégiben elfogadott, a közvetítői tevékenységről szóló törvény főbb rendelkezéseit. A könyv összehasonlítja a mediációt és a választottbíráskodást, bemutatja a hazai és a külföldi közvetítői tevékenység szabályait és gyakorlatát a mediáció különböző területein (családi, munkaügyi, egészségügyi, fogyasztóvédelmi stb. közvetítés). (F. Á.)

- Nagykommentár a fizetési meghagyásos eljárásról szóló törvényhez

SZÉCSÉNYI-NAGY Kristóf

CompLex Kiadó, Budapest, 2012

Jogszabálykommentár. Terjedelem: 527 . Bibliográfia a kiadvány elején. ISBN 9789632952239

- A szerző egyetemi oktató és egyben gyakorló jogász. A kiadvány a fizetési meghagyásról szóló 2009. évi L. törvény részletes magyarázata mellett nagy figyelmet fordít a kapcsolódó közjegyzői gyakorlat bemutatására is. Tekintettel arra, hogy az Fmhtv. nem ragadható ki a jogszabályi környezetből, ezért a szerző a Pp. fontosabb kapcsolódó szabályait, továbbá a rendeleti szintű háttéranyagot is bemutatja. A kiadvány elsődlegesen a jogalkalmazás számára kíván segítséget nyújtani, éppen ezért külön is kitér a megelőző két évben felmerült gyakorlati kérdések lehetséges megoldásaira. A szerző minden esetben külön is ismerteti a saját álláspontját az egyes kérdésekben, mely a jövőbeni szakmai diskurzusok kiindulópontja is lehet. (F. Á.) 
- Az új Polgári Törvénykönyv Bizottsági Javaslata magyarázatokkal Vékás Lajos-Gárdos Péter (szerk.)

CompLex Kiadó, Budapest, 2012

Törvényjavaslat-magyarázat. Terjedelem: 616. Bibliográfia nincs. ISBN 9789632249988

- A jelen kötet az új Polgári törvénykönyv kodifikációs föbizottsági szövegét (Javaslat) teszi közzé magyarázatokkal. A normaszöveget a kötet szerkesztője által elnökölt Kodifikációs Főbizottság 2011. december 16-i ülésén fogadta el. A magyarázatok elsősorban arról kívánják tájékoztatni az olvasót, hogy miben változtat a Javaslat a hatályos polgári jogon (elsősorban a Ptk.-hoz képest, de adott esetben a külön törvényekhez és a bírói gyakorlathoz képest is), és miért kerül sor ezekre a módosításokra. A változtatásokon és azok indokain kívül a magyarázatok kitérnek a Javaslat egyéb forrásaira is, mindenekelőtt azokra az uniós irányelvekre, amelyeknek a kódexbe történő beépítése feltétlenül indokoltnak látszott. (K. G. M.) 